\title{
Indole hybridized diazenyl derivatives: synthesis, antimicrobial activity, cytotoxicity evaluation and docking studies
}

Harmeet Kaur ${ }^{1}$, Jasbir Singh ${ }^{2}$ and Balasubramanian Narasimhan ${ }^{1 *}$ (D)

\begin{abstract}
Background: In search of effective antimicrobial and cytotoxic agents, a series of indole hybridized diazenyl derivatives (DS-1 to DS-21) was efficiently prepared by condensation of diazotized $p$-aminoacetophenone with indole or nitroindole followed by reaction with different aromatic/heteroaromatic amines of biological significance. The synthesized derivatives were characterized by various spectroscopic techniques.

Methodology: The antimicrobial evaluation of DS-1 to DS-23 was done by tube dilution method against various pathogenic bacterial and fungal strains. The active antimicrobial derivatives were further evaluated for cytotoxicity against human lung carcinoma cell line (HCT-116), breast cancer cell line (MDAMB231), leukemic cancer cell line (K562), and normal cell line (HEK293) by MTT assay using doxorubicin as the standard drug. The test derivatives were additionally docked for the B-subunit of enzyme DNA gyrase from E. coli at the ATPase binding site to study the molecular interactions using Schrodinger maestro v11.5 software.

Results and discussion: Most of the synthesized derivatives have shown high activity against Gram-negative bacteria particularly E. coli and K. pneumonia with MIC ranging from 1.95 to $7.81 \mu \mathrm{g} / \mathrm{ml}$. The derivatives have demonstrated very less activity against tested Gram positive bacterial and fungal strains. The derivatives DS-14 and DS-20 have been found to active against breast cancer cell line and human colon carcinoma cell line having $I C_{50}$ in the range of 19-65 $\mu \mathrm{g} / \mathrm{ml}$. All the derivatives were found to less potent against leukemic cancer cell line. The synthesized derivatives have revealed their safety by exhibiting very less cytotoxicity against the normal cell line (HEK-293) with $\mathrm{IC}_{50}>100 \mu \mathrm{g} / \mathrm{ml}$. Most of the active derivatives have shown good docking scores in comparison to the standard drugs against DNA gyrase from E. coli. Further ADME predictions by Qikprop module of the Schrodinger confirmed these molecules have drug like properties.
\end{abstract}

Conclusion: The derivatives DS-14 and DS-20 have shown potential against Gram-negative bacteria and breast cancer cell line and can be used as a lead for rational drug designing of the antimicrobial and cytotoxic agents..

Keywords: Diazenyl, Indole, Antimicrobial, Cytotoxicity, Docking

*Correspondence: naru2000us@yahoo.com

${ }^{1}$ Faculty of Pharmaceutical Sciences, Maharshi Dayanand University,

Rohtak 124001, India

Full list of author information is available at the end of the article

(c) The Author(s) 2019. This article is distributed under the terms of the Creative Commons Attribution 4.0 International License (http://creativecommons.org/licenses/by/4.0/), which permits unrestricted use, distribution, and reproduction in any medium, provided you give appropriate credit to the original author(s) and the source, provide a link to the Creative Commons license, and indicate if changes were made. The Creative Commons Public Domain Dedication waiver (http://creativecommons.org/ publicdomain/zero/1.0/) applies to the data made available in this article, unless otherwise stated. 


\section{Introduction}

The burgeoning number of the infectious diseases due to the growing concerns of the antimicrobial resistance (AMR) has been presented the major threat to the existence of the mankind $[1,2]$. The World Health Organization report in 2016 disclosed that tuberculosis, diarrhoea and respiratory infections are among the top ten diseases with the accountability of approximately 5.7 million deaths worldwide [3]. A recent report estimated that the microbial infections would cause 10 million deaths annually by 2050 [4]. The treatment options for the contagious diseases conferred a complicated mystery in the early 1900, but it was unlocked by the accidental discovery of the penicillin in 1928, the first antibiotic, by Alexander Fleming, resulted in the beginning of antibiotic era [5]. Afterwards, the modern medicine have been revolutionized by the antibiotics and blessed the millions of human lives. But the overproduction, inappropriate and extensive use, poor infection control, poor hygiene and sanitation, discovery of fewer new antibiotics have led to the development of antimicrobial resistance [6]. From the late 1960 to early 1990, various new antibiotics have been introduced by the pharmaceutical industry to conquer the drug resistance dilemma, but later on the number of investigating antibiotics in clinical trials dramatically decreased and only a bunch of new antibiotics have been introduced in the market. The concern of pharmaceutical industry has been also shifted from the discovery of antimicrobials to the drugs dealing with other lethal diseases due to socio-economic and financial factors [79]. According to a study by the Pew Charitable Trusts in 2016, each currently available antibiotic is derived from a pre-existing class discovered by 1984 [10]. Hence the post-antibiotic era will represent the future panorama of the world with the high mortality rates due to the common infections. This situation has been further inflamed as most of the other malignant diseases with the host immune-compromised or concomitant illness especially cancer often accompanied by the microbial infections $[11,12]$. The cancer patients are at the higher risk of microbial infections as compared to the normal persons due to the easy access of the microorganisms as a result of interrupted epithelial barriers, compromised host defence, the absence of neutrophils, and shifts in the microbial flora, etc. [13, 14]. Mostly patients diagnosed with cancer are also recommended with the antibiotics to increase the life span. The most lethal cancers have also developed resistance to the current chemotherapeutic agents hence presented the limited treatment scope [15]. All above facts necessitates the need for the development of new antimicrobial and cytotoxic agents and also signifies the importance of understanding the mechanisms of drug interactions on a molecular level to further enhance the development of new antimicrobial and anticancer agents.

DNA gyrases are well-studied drug targets that are present in almost all bacteria and are essential for growth of bacteria $[16,17]$. The low structural homology exhibited by these enzymes with human topoisomerases make them attractive drug targets for antibacterial therapy. Mostly these enzymes consist of two subunits. The B-subunit of DNA gyrase (GyrB) consist of ATP binding pockets which are responsible for the DNA replication. The small molecules inhibition of this pocket is plausible, and several lead compounds have been developed by targeting this pocket $[18,19]$.

The indole derivatives have been emerged as the drugs of immense importance in the recent times and well known for their significant biological activities such as cytotoxic, antimicrobial, antidiabetic, and anti-inflammatory activities [20-23]. Several indole containing drugs are available in the market. Some of the indole containing drugs have been listed in Fig. 1.

Likewise, diazenyl compounds characterized by the presence of azo linkage $(-\mathrm{N}=\mathrm{N}-)$ have also attracted the attention of the researchers due to their significant biological activities. Many diazenyl derivatives (i.e. diazeniumdiolate prodrugs, diazenecarboxamides, diazenyl complexes etc.) have been accounted for their cytotoxic potential towards different cancerous cell lines in the recent years [24-26]. These derivatives also reported to have antimicrobial activity $[27,28]$.

In perspective of above details, in the current study we have planned to synthesize the novel hybridized indole diazenyl derivatives using different aromatic/heteroaromatic amines of biological significance and evaluate their antimicrobial potential against various pathogenic strains and also against a number of cancerous cell lines for evaluation of their cytotoxic potential. Additionally, these derivatives also have been planned to study for the molecular interactions with the B-subunit of enzyme DNA gyrase at the ATP binding pocket.

\section{Results and discussion \\ Chemistry}

The target compounds (DS1-DS21) were synthesized from the commercially available $p$-aminoacetophenone which was diazotized in the presence of $\mathrm{NaNO}_{2}$ and $\mathrm{HCl}$ followed by condensation with unsubstituted indole or nitroindole and further reaction with various amines of biological significance (Fig. 2). The amine, tetrahydrobenzothiophene used for synthesis of derivative DS-2 was prepared by the Gewald reaction [29]. The amines used for the synthesis of DS-3, DS-5 and DS-7 were prepared by the reaction of aliphatic/aromatic carboxylic acids with the $\mathrm{POCl}_{3}$ and thiosemicarbazide as 
<smiles>CN1C(=N)NC(=O)/C1=C\c1c[nH]c2cc(Br)ccc12</smiles>

6-Bromoaplysinosin (Antidepressant)<smiles>CC(C)NC1=C(N2CCN(C(=O)C3CC4CC(NS(C)(=O)=O)CCC4N3)CC2)NCCC1</smiles>

Delavirdine (Antiviral)<smiles>CCN(CC)CCNC(=O)c1c(C)[nH]c(/C=C2\C(=O)Nc3ccc(F)cc32)c1C</smiles>

Brivanib (Anticancer)

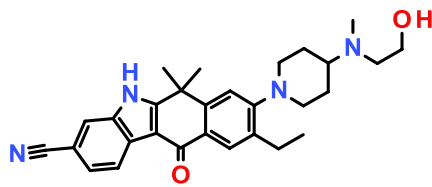

Alectinib (Anticancer)

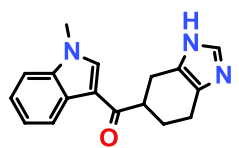

Ramosetron (Antiemetic)

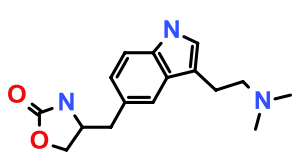

Zolmitriptan (Antimigraine)

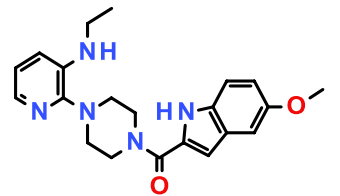

Atevirdine (Antiviral)

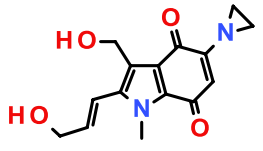

Apaziquinone(Anticancer)

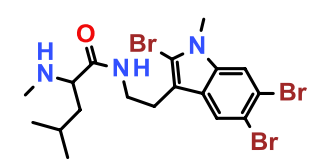

Altematamide (Antimicrobial)

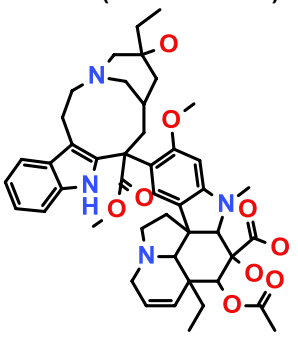

Vincristine (Anticancer)<smiles></smiles>

Mitraphylline(Anticancer)

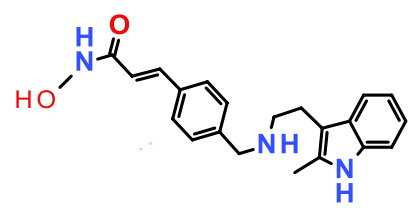

Panobinostat (Antileukaemic)<smiles>Cc1cc2c(F)c(Oc3ncnc4ncncc34)ccc2[nH]1</smiles>

Brivanib (Anticancer)<smiles>COc1cc(C(=O)NS(=O)(=O)c2ccccc2C)ccc1Cc1cn(C)c2ccc(NC(=O)OC3CCCC3)cc12</smiles>

Zafirlukast (Antiasthmatic)

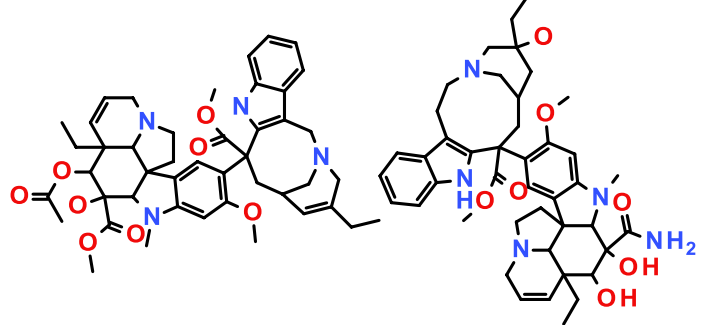

Vindesine (Anticancer)

Fig. 1 Indole containing drug molecules

per the reported methods [30, 31]. The compounds DS4, DS-8, DS-9, DS-12 and DS-18 were not mentioned in the scheme as these compounds do not meet the criteria of purity for the synthesized compounds. The structures of test compounds have been verified by IR, ${ }^{1} \mathrm{H}-\mathrm{NMR}$, ${ }^{13} \mathrm{C}-\mathrm{NMR}$, and mass spectroscopy.

The IR spectrum of synthesized compounds was determined by $\mathrm{KBr}$ pellet method. The $\mathrm{NH}$ stretch due to indole moiety was observed at $3217-3447 \mathrm{~cm}^{-1}$. The $\mathrm{C}=\mathrm{O}$ group in dyes $\mathbf{1}$ and $\mathbf{2}$ was detected between 1668 and $1669 \mathrm{~cm}^{-1}$ respectively which was shifted to the 1601-1641 $\mathrm{cm}^{-1}$ in DS-1 to DS-23 indicating the formation of Schiff base $(-\mathrm{CH}=\mathrm{N}-$ linkage). The aliphatic stretch was perceived in the range of $2847-3169 \mathrm{~cm}^{-1}$. The compound having ester group (DS-2) exhibited $\mathrm{C}=\mathrm{O}$ stretching at the $1721 \mathrm{~cm}^{-1}$. The $-\mathrm{C}=\mathrm{C}-$ stretch of the aromatic rings appeared at $1512-1596 \mathrm{~cm}^{-1}$. The presence of band at $1401-1468 \mathrm{~cm}^{-1}$ confirmed the presence of azo linkage. The other peaks observed are the $\mathrm{C}-\mathrm{N}$ stretching between 1011 and $1335 \mathrm{~cm}^{-1}$, Ar-O stretching at $1108-1278 \mathrm{~cm}^{-1},-\mathrm{C}=\mathrm{C}-$ bending at $682-$ $747 \mathrm{~cm}^{-1}$, and $\mathrm{C}-\mathrm{S}$ stretching at $617-701 \mathrm{~cm}^{-1}$. The $\mathrm{NO}_{2}$ stretch confirmed by the two strong bands at 1319 $1338 \mathrm{~cm}^{-1}$ and $1468-1517 \mathrm{~cm}^{-1}$. The bands in the range of $535-1053 \mathrm{~cm}^{-1}$ have been assigned to the C-X (halogen) absorption. The proton NMR spectra of synthesized compounds were taken in DMSO at $400 \mathrm{MHz}$. The proton spectra of mostly synthesized compounds exhibited peak at 11.19-12.65 ppm due to the presence of $-\mathrm{NH}$ of the indole moiety. The signals of the aromatic protons have been observed in the range of $\delta 6.37-8.58 \mathrm{ppm}$. The protons of the ethoxy group in DS-2 produced a classic triplet-quartet signal pattern at $\delta 1.27 \mathrm{ppm}$ and $4.13 \mathrm{ppm}$ respectively. The proton signal of the methylene group as in the case of DS-1 appeared as a singlet at $4.23 \mathrm{ppm}$. The proton of the carboxyl group appeared in the range of $\delta 10.24-11.59 \mathrm{ppm}$. The protons of the saturated carbons of the cyclohexenyl ring appeared 


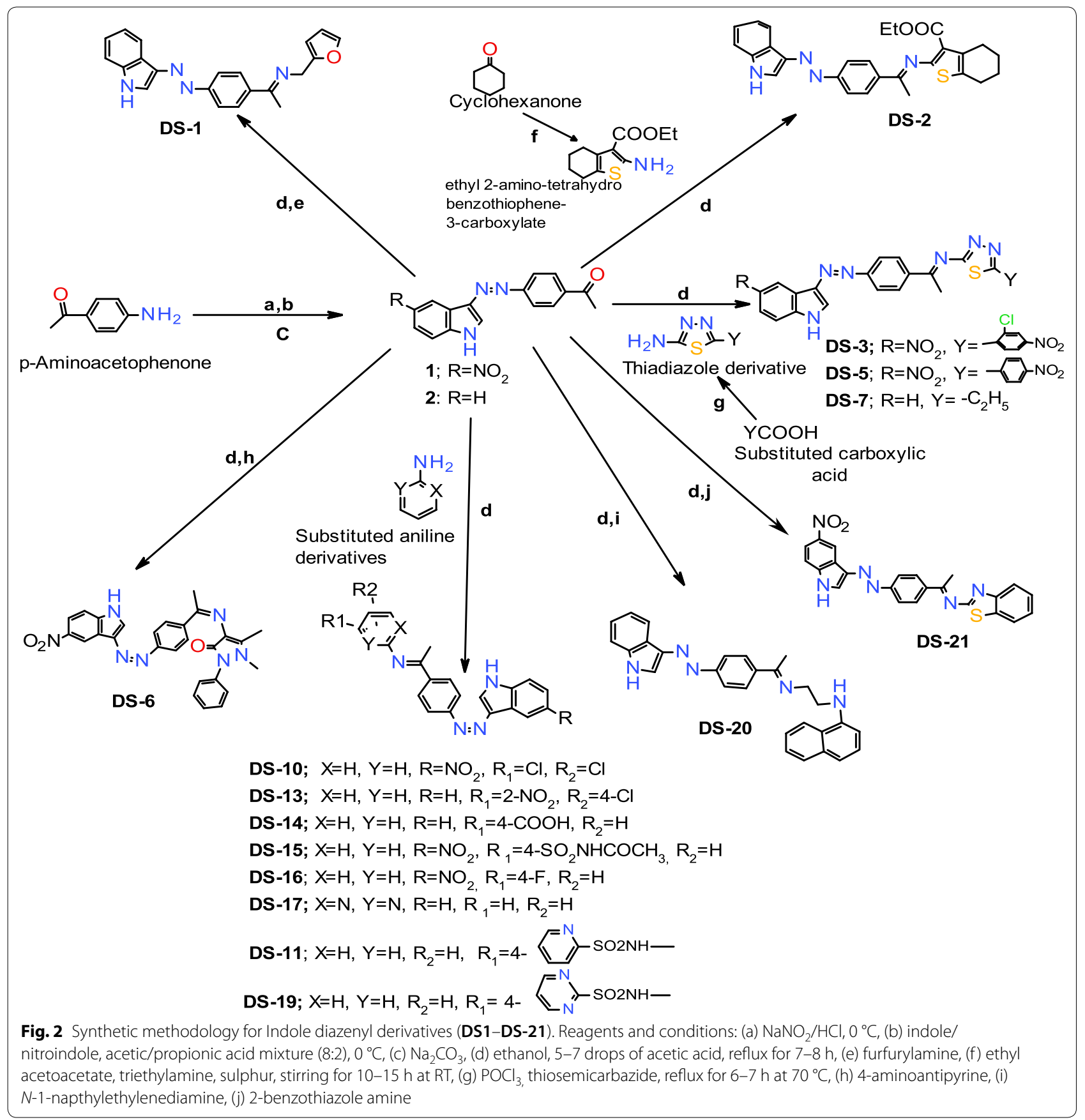

as two multiplets at $\delta 2.73\left(4 \mathrm{H}, 2 \mathrm{CH}_{2}\right)$ and $\delta 1.85(4 \mathrm{H}$, $2 \mathrm{CH}_{2}$ ). The proton correspond to the sulphonamide ($\left.\mathrm{SO}_{2} \mathrm{NH}-\right)$ moiety in DS-11 and DS-19 appeared in the range of 5.91-5.98 ppm. The protons of methyl group were observed in the range of $1.80-2.31 \mathrm{ppm}$. The carbon signals of the aromatic carbons in ${ }^{13} \mathrm{C}$ NMR spectrum of DS-1 to DS-21 were observed between 108 and $159 \mathrm{ppm}$. The ${ }^{13} \mathrm{C}$ NMR peaks at $165-177 \mathrm{ppm}$ accounted for the carbonyl group. The carbon of the imine group was observed between 160 and $165 \mathrm{ppm}$. The ethoxy carbons appeared at the 61 and $14 \mathrm{ppm}$ respectively. The peak in the range of 45-58 ppm represented the methylene carbons. The carbon signals of saturated carbons of the cylohexenyl ring appeared in the range of $20-28 \mathrm{ppm}$. The final confirmation of the synthesized compounds was done by mass spectroscopy. The $\%$ of $\mathrm{C}, \mathrm{O}, \mathrm{N}, \mathrm{H}$ and $\mathrm{S}$ in the target compounds was found to be within the defined limits. 
Table $1 \mathrm{MIC}$ in $\mu \mathrm{g} / \mathrm{ml}$ of synthesized indole hybridized diazenyl derivatives

\begin{tabular}{|c|c|c|c|c|c|c|c|}
\hline Compd. & E. coli & S. aureus & S. enterica & B. subtilis & K. pneumonia & A. niger & A. fumigatus \\
\hline \multicolumn{8}{|c|}{ MIC $(\mu \mathrm{g} / \mathrm{ml})$} \\
\hline DS-1 & 15.62 & 62.5 & 62.5 & 62.5 & 3.90 & 125 & 62.5 \\
\hline DS-2 & 15.62 & 62.5 & 15.62 & 31.25 & 31.25 & 62.5 & 15.62 \\
\hline DS-3 & 3.90 & 62.5 & 31.25 & 31.25 & 1.95 & 62.5 & 15.62 \\
\hline DS-5 & 1.95 & 125 & 31.25 & 62.5 & 3.90 & 62.5 & 125 \\
\hline DS-6 & 1.95 & 31.25 & 31.25 & 31.25 & 7.81 & 62.5 & 31.25 \\
\hline DS-7 & 7.81 & 62.5 & 31.25 & 125 & 3.90 & 62.5 & 62.5 \\
\hline DS-10 & 1.95 & 62.5 & 31.25 & 62.5 & 3.90 & 62.5 & 125 \\
\hline DS-11 & 3.90 & 31.25 & 62.5 & 31.25 & 15.62 & 125 & 62.5 \\
\hline DS-13 & 7.81 & 62.5 & 62.5 & 62.5 & 3.90 & 62.5 & 31.25 \\
\hline DS-14 & 3.90 & 62.5 & 1.95 & 31.25 & 1.95 & 62.5 & 31.25 \\
\hline DS-15 & 15.62 & 125 & 31.25 & 31.25 & 3.90 & 125 & 62.5 \\
\hline DS-16 & 15.62 & 62.5 & 62.5 & 31.25 & 7.81 & 62.5 & 31.25 \\
\hline DS-17 & 3.90 & 62.5 & 62.5 & 125 & 7.81 & 62.5 & 31.25 \\
\hline DS-19 & 7.81 & 31.25 & 62.5 & 31.25 & 15.26 & 31.25 & 31.25 \\
\hline DS-20 & 1.95 & 125 & 15.62 & 125 & 3.90 & 62.5 & 62.5 \\
\hline DS-21 & 3.90 & 62.5 & 31.25 & 31.25 & 3.90 & 125 & 125 \\
\hline CFT & 1.95 & 15.62 & 15.62 & 15.62 & 1.95 & - & - \\
\hline CPR & 3.90 & 1.95 & 15.62 & 7.81 & 7.81 & - & - \\
\hline FLU & - & - & - & - & - & 31.25 & 7.81 \\
\hline
\end{tabular}

CFT cefotaxime, CPR ciprofloxacin, FLU fluconazole

Table $2 \mathrm{MBC} / \mathrm{MFC}$ in $\mu \mathrm{g} / \mathrm{ml}$ of synthesized indole hybridized diazenyl derivatives (DS1-DS21)

\begin{tabular}{|c|c|c|c|c|c|c|c|}
\hline Compound & E. coli & S. aureus & S. enterica & B. subtilis & K.pneumonia & A. niger & A. fumigatus \\
\hline \multicolumn{8}{|c|}{ MBC/MFC ( $\mu \mathrm{g} / \mathrm{ml})$} \\
\hline DS-1 & 125 & 125 & 62.5 & 125 & 7.81 & 125 & 125 \\
\hline DS-2 & 16.25 & 125 & 15.62 & 125 & 62.5 & 125 & 62.5 \\
\hline DS-3 & 31.25 & 62.5 & 31.25 & 62.5 & 31.25 & 125 & 62.5 \\
\hline DS-5 & 31.25 & 125 & 62.5 & 125 & 15.62 & 125 & 125 \\
\hline DS-6 & 3.90 & 31.25 & 31.25 & 62.5 & 7.81 & 125 & 125 \\
\hline DS-7 & 31.25 & 125 & 31.25 & 125 & 16.25 & 125 & 125 \\
\hline DS-10 & 31.25 & 125 & 62.5 & 125 & 7.81 & 125 & 125 \\
\hline DS-11 & 62.5 & 62.5 & 125 & 125 & 31.25 & 125 & 125 \\
\hline DS-13 & 3.90 & 62.5 & 62.5 & 125 & 15.62 & 125 & 125 \\
\hline DS-14 & 7.81 & 62.5 & 7.81 & 62.5 & 3.90 & 125 & 125 \\
\hline DS-15 & 125 & 31.25 & 31.25 & 62.5 & 31.25 & 125 & 125 \\
\hline DS-16 & 62.5 & 125 & 62.5 & 125 & 31.25 & 125 & 125 \\
\hline DS-17 & 15.62 & 62.5 & 62.5 & 62.5 & 15.62 & 125 & 125 \\
\hline DS-19 & 62.5 & 31.25 & 62.5 & 125 & 15.62 & 125 & 125 \\
\hline DS-20 & 7.81 & 62.5 & 31.25 & 125 & 15.62 & 125 & 125 \\
\hline DS-21 & 7.81 & 62.5 & 31.25 & 62.5 & 7.81 & 125 & 125 \\
\hline CFT & 15.62 & 31.25 & 31.25 & 15.62 & 3.90 & - & - \\
\hline CPR & 31.25 & 62.5 & 31.25 & 31.25 & 7.81 & - & - \\
\hline FLU & - & - & - & - & - & 125 & 125 \\
\hline
\end{tabular}

CFT cefotaxime, CPR ciprofloxacin, FLU fluconazole 


\section{Biological activity Antimicrobial results}

The antimicrobial evaluation was done for the synthesized indole derivatives (DS-1 to DS-21) in terms of MIC and $\mathrm{MBC}$ values in $\mu \mathrm{g} / \mathrm{ml}$ using standard antibacterial drugs (ciprofloxacin and cefotaxime) and antifungal drug (fluconazole). The results of antimicrobial evaluation has been presented in Tables 1 and 2 respectively. The most of the indole derivatives had shown the highest activity against Gram-negative bacteria particularly E. coli and K. pneumonia with MIC ranges from 1.95 to $7.81 \mu \mathrm{g} / \mathrm{ml}$ comparable with the standard drugs. The derivative DS14 having substituted $p$-carboxy phenyl ring attached with the indole diazenyl scaffold was found most active against E. coli, S. enterica and K. pneumonia with MIC of 1.95-3.90 $\mu \mathrm{g} / \mathrm{ml}$. The derivatives DS-6, DS-13, DS-14, DS-20, and DS-21 not only acted as bacteriostatic agents but also as bactericidal agents against $E$. coli by exhibiting low $\mathrm{MBC}$ values $(3.90-7.81 \mu \mathrm{g} / \mathrm{ml})$ in comparison to the standard drugs $(15.62-31.25 \mu \mathrm{g} / \mathrm{ml})$. Similarly, the derivatives DS-1, DS-6, DS-10, DS-14, and DS-21 also acted as bactericidal agents against $K$. pneumonia with $\mathrm{MBC}$ values $(3.90-7.81 \mu \mathrm{g} / \mathrm{ml})$ in comparison with the standard drugs. The derivatives DS-2 and DS-3 had shown moderate activity against fungal strain $A$. fumigatus having $\mathrm{MIC}$ of $15.62 \mu \mathrm{g} / \mathrm{ml}$ as compared to the standard drug fluconazole ( $\mathrm{MIC}=7.81 \mu \mathrm{g} / \mathrm{ml}$ ). All of the synthesized derivatives had shown less activity against tested Gram-positive bacteria (S. aureus and B. subtilis) and fungal strain $(A$. niger) with $\mathrm{MIC}>10 \mu \mathrm{g} / \mathrm{ml}$. These results clearly indicated that Gram negative bacteria were more susceptible to the synthetic indole derivatives.

From the SAR studies it was elucidated that

- The indole diazenyl scaffold is essential for activity against Gram-negative bacteria particularly E. coli and K. pneumonia.

- The derivative (DS-14) with substituted phenyl ring having carboxy group at the para position showed remarkable activity against tested Gram-negative bacteria.

- The derivative DS-1 (with substituted furfuryl ring attached with the indole diazenyl scaffold) exhibited more activity against $K$. pneumonia as compared to E. coli.

- The derivatives DS-6 (substituted pyrazole ring), DS20 (substituted ethylaminonapthyl ring) and DS-21 (having substituted benzothiazolyl ring) acted as bactericidal agents against $K$. pneumonia and E. coli.

- The derivatives DS-2 (substituted tetrahydrobenzothiophene ring) and DS-3 (substituted thiadiazole ring) exhibited activity only against fungal strain $A$. fumigatus.
- The compounds DS-11 and DS-19 with substituted sulfa drugs (sulfapyridine and sulfadiazine) exhibited activity only against E. coli and acted as bacteriostatic agents.

- The most of the synthesized compounds were found to inactive against tested Gram-positive bacterial strains and fungal strain $A$. niger.

\section{Anticancer results}

The selected compounds DS-2, DS-3, DS-6, DS-10, DS-14, DS-20 and DS-21 have been evaluated for cytotoxicity against human lung carcinoma cell line (HCT-116), breast cancer cell line (MDA MB231), leukemic cancer cell line (K562), and normal cell line (HEK293) by MTT assay using doxorubicin as the standard drug. The results of anticancer screening have been presented in Table 3 . The $\mathrm{IC}_{50}$ was calculated from the survival curve plots which were drawn between \% cell viability and concentration of the compounds. The experiment was performed in triplicate. The different cells treated with different concentrations of the test derivatives were also observed under inverted phase microscope (Biolink) at $48 \mathrm{~h}$ for various morphological changes like density of cells, shape of the cells, and any signs of shrinkage. The derivatives DS-2, DS-3, DS-14, DS-20 and DS-21 have shown cytotoxicity towards breast cancer cell line (MDA MB 231) with $\mathrm{IC}_{50}$ in the range of $20-60 \mu \mathrm{g} / \mathrm{ml}$ as compared to the standard drug doxorubicin $\left(\mathrm{IC}_{50}=3 \mu \mathrm{g} / \mathrm{ml}\right)$. In Fig. 3, it is evident that the test derivatives have reduced the number and clumping of MDA MB 231 cells. The higher

\begin{tabular}{|c|c|c|c|c|}
\hline Compound & HCT $116^{a}$ & $\begin{array}{l}\text { MDA MB } \\
231^{b}\end{array}$ & K562 & HEK-293 \\
\hline \multicolumn{5}{|l|}{$\mathrm{IC}_{50}(\mu \mathrm{g} / \mathrm{ml})$} \\
\hline DS-2 & $116.57 \pm 4.28$ & $57.63 \pm 3.68$ & $140.05 \pm 4.40$ & $280.24 . \pm 1.74$ \\
\hline DS-3 & $110.03 \pm 2.55$ & $45.96 \pm 1.83$ & $146.08 \pm 2.11$ & $311.17 \pm 1.76$ \\
\hline DS-6 & $139.19 \pm 4.29$ & $118.73 \pm 1.92$ & $187.76 \pm 1.94$ & $257.84 \pm 0.57$ \\
\hline DS-10 & $204.93 \pm 1.62$ & $129.66 \pm 3.51$ & $198.55 \pm 3.13$ & $274.12 \pm 4.58$ \\
\hline DS-14 & $54.03 \pm 1.96$ & $19.10 \pm 1.43$ & $112.26 \pm 3.64$ & $244.15 \pm 3.78$ \\
\hline DS-20 & $66.66 \pm 1.56$ & $20.95 \pm 1.93$ & $135.80 \pm 4.74$ & $232.69 \pm 4.68$ \\
\hline DS-21 & $124.80 \pm 1.33$ & $49.30 \pm 4.15$ & $157.95 \pm 3.73$ & $141.92 \pm 3.25$ \\
\hline DOX & $3.37 \pm 0.37$ & $3.08 \pm 0.95$ & $2.62 \pm 0.65$ & NT \\
\hline
\end{tabular}

$\mathrm{IC}_{50}=50 \%$ Inhibitory concentration after $48 \mathrm{~h}$ of drug treatment DOX doxorubicin, NT not tested

a Colon cancer

b Breast cancer

c Leukemia

d Normal cells 


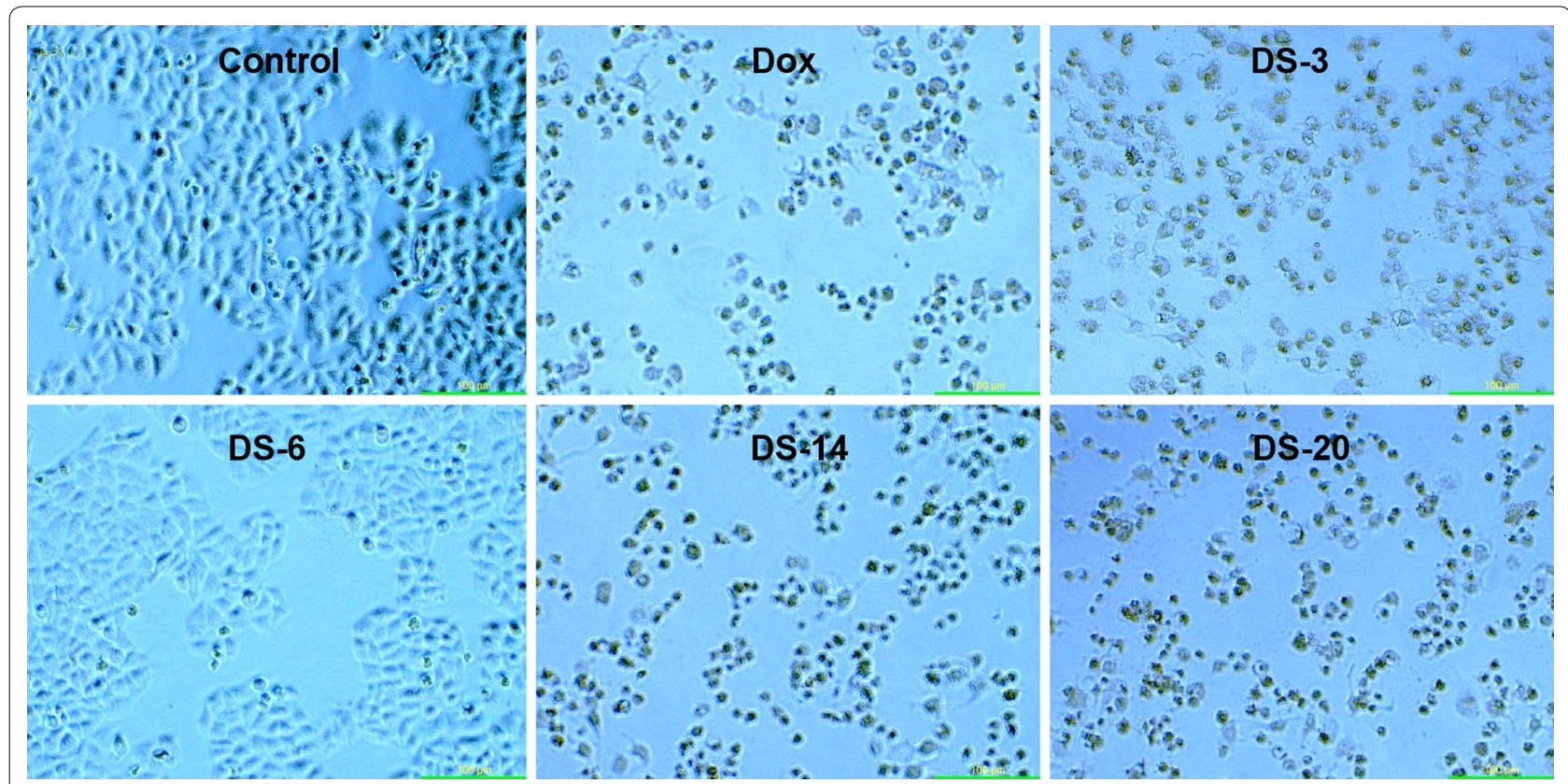

Fig. 3 Morphological characterization of control, standard and various test compounds against MDAMB 231 cell line at $50 \mu \mathrm{g} / \mathrm{ml}$ using inverted phase microscope (Biolink) after $48 \mathrm{~h}$

concentrations of the test derivatives have significantly reduced the number of MDA MB231 cells. The derivatives DS-14 and DS-20 had also shown moderate activity against human colon carcinoma cell line (HCT116) with MIC of $54-67 \mu \mathrm{g} / \mathrm{ml}$. None of the tested derivative had shown significant activity towards the leukemic cancer cell line (K562). The selected compounds were also evaluated for their possible cytotoxicity in human embryonic kidney cells (HEK-293) by employing MTT assay. The assay results suggested that these compounds did not significantly affect the growth of normal kidney cells (As most of the compounds $\mathrm{IC}_{50}$ values are $>100$ ). Hence, these compounds revealed their safety for the normal cells and the compounds DS-14 and DS-20 can be taken as lead compounds for further development of more potential agents for breast cancer.

\section{Molecular docking}

Bacterial DNA gyrase is the key enzyme and the target for the development of the newer antibacterial drugs [32]. DNA gyrase consists of 2 subunits-subunit A and subunit B. Subunit A nicks the dsDNA, subunit B introduces -ve supercoils and then subunit A reseals the ends. [33]. Further the functions of the DNA gyrase in humans are performed by the group of topoisomerase enzymes. The natural product (e.g., coumarin) and synthetic compounds (e.g., quinolone) are well known inhibitors of bacterial gyrase [34]. The coumarin antibiotics, novobiocin and its dimer coumermycin A1 are characteristic examples, which inhibit the subunit B of DNA gyrase. But the use of these inhibitors has been restricted due to emergence of drug resistance [35]. Therefore, targeting subunit B might produce some novel DNA gyrase inhibitors.

In the DNA gyrase subunit B, there is an ATP binding pocket, where ATP bind and on hydrolysis activate the enzyme for the further function. Thus targeting this site might be effective to produce novel DNA gyrase inhibitors. In an effort to find out the new inhibitors of the GyrB subunit ATP binding site and minimize targetbased resistance, the target compounds were docked on the ATPase binding site of GyrB from E. coli (PDB:4KFG). The molecular docking study was carried out on GLIDE docking program and the results were analyzed based on the docking score, glide energy, glide energy model obtained from GLIDE and presented in Table 4. The predicted docking poses were visually inspected and interactions with the binding pocket residues were analyzed using the ligand-interactions diagrams. The docking results showed that the studied compounds can be accommodated in the binding pocket of GyrB subunit with a comparable orientation to the one observed in the co-crystallised ligand covalent adduct in the reported crystal structure (4KFG). The best docked pose for the highest active compounds DS-6, DS-11, DS-14, DS-20 have been presented in Figs. 4, 5, 6, and 7 respectively. The docking scores were demonstrated in terms of negative energy; the lower the binding energy, best would 
Table 4 Glide docking scores of Indole diazenyl derivatives (DS1-DS21) against GyrB subunit (4KFG)

\begin{tabular}{lllll}
\hline S. no & Glide Emodel & Glide energy & Glide evdw & Docking score \\
\hline DS-1 & -61.121 & -45.842 & -44.011 & -4.332 \\
DS-2 & -84.18 & -56.696 & -51.197 & -4.356 \\
DS-3 & -106.573 & -64.868 & -62.844 & -3.182 \\
DS-6 & -81.579 & -59.847 & -56.86 & -5.255 \\
DS-7 & -65.006 & -49.231 & -44.718 & -3.981 \\
DS-10 & -72.221 & -49.484 & -47.959 & -4.477 \\
DS-11 & -89.575 & -64.032 & -53.014 & -5.469 \\
DS-13 & -67.971 & -54.886 & -49.797 & -4.022 \\
DS-14 & -79.274 & -54.871 & -47.968 & -5.123 \\
DS-15 & -90.979 & -55.621 & -59.366 & 0.647 \\
DS-16 & -78.016 & -53.488 & -52.037 & -4.902 \\
DS-17 & -65.955 & -46.798 & -44.872 & -4.119 \\
DS-19 & -88.711 & -60.349 & -51.526 & -5.411 \\
DS-20 & -83.895 & -56.311 & -52.249 & -5.921 \\
DS-21 & -89.289 & -59.604 & -57.047 & -3.864 \\
CFT & -83.319 & -57.891 & -50.792 & -6.459 \\
CPR & -51.008 & -41.768 & -39.321 & -5.071 \\
NOV & -60.31 & -50.268 & -37.426 & -3.455 \\
\hline
\end{tabular}

CFT cefotaxime, CPR ciprofloxacin, NOV novobiocin

be the binding affinity. The most of the compounds have shown good docking scores and low binding energies as compared to the standard drug novobiocin and comparable scores with the ciprofloxacin. The highest docking score $(-5.921)$ was observed for DS20 followed by DS-11 (- 5.469) and DS-14 (- 5.123) in comparison to the standard drugs novobiocin $(-3.455)$ and ciprofloxacin $(-5.071)$.

The synthesized indole diazenyl derivatives (DS-1 to DS-21) showed that in most of the active inhibitors the interactions were dominated by the hydrogen bonding (1.34-1.98 $\AA$ ) due to the presence of $-\mathrm{NH}$ of the indole moiety with the essential Asp73 residue of the binding site (same interaction as in case of co-crystallised ligand). The most of the active inhibitors exhibited hydrogen bonding network with Asn46, Asp73, Arg76, Val120, the key residues belonging to the catalytic domain of the GyrB enzyme amino acid stretch. The compounds with substituted nitro group exhibited two salt bridges through nitrogen and oxygen of nitro group with the key residues $\operatorname{Arg} 76(4.62 \AA)$ and Glu50 (4.64 $\AA$ ). The active compound DS-11 exhibited three hydrogen bonding interactions: $-\mathrm{NH}-$ of the indole moiety with the Asp73 residue $(1.49 \AA),-\mathrm{S}=\mathrm{O}$ moiety with the Val120 residue $(2.71 \AA)$, through sulfamoyl -NH moiety with the Asn46 residue (2.34 $\AA$ ). Another active compound DS-6 did not display any $\mathrm{H}$-bonding interaction with the key amino acid residues. The main interactions dominated in this compound are electrostatic and hydrophobic interactions at the several key residues. The interacting amino acids at the active site with the different test compounds have been presented in Table 5. Overall the docking results validated the antimicrobial activity and these indole diazenyl derivatives can be developed as lead compounds as DNA gyrase inhibitors.

\section{ADME results}

Mostly drugs failed during the clinical development due to the ADME/Tox deficiencies. So, the virtual screening should not be limited to improve selectivity and optimize binding affinity; but the pharmacokinetic parameters should also be involved as significant filters in virtual screening [36]. Over-all 44 descriptors and pharmaceutically pertinent properties of substituted indole diazenyl analogs were investigated using Qikprop (QikProp, version 3.5, Schrödinger) in comparison with those of $95 \%$ of known drugs [37]. Some of the important descriptors essential for envisaging the drug like properties of molecules are reported in Table 6 . The most of the synthesized compounds have followed the Lipinski's rules: molecular weight $<500 \mathrm{Da}$, octanol/water partition coefficient $(\mathrm{QPlogPo} / \mathrm{w})<5$, hydrogen bond acceptor $<10$ and donor $<5$. The $\%$ oral absorption was found in the range of $80-100 \%$ in most of the derivatives.

\section{Experimental}

\section{Materials and methods}

The required synthetic chemicals were purchased from Merck Chemicals (India) and utilized without further purification. The reagents for the antimicrobial evaluation and for the cytotoxicity study were procured from Hi-Media Laboratories (India). The microbial strains were acquired from Institute of Microbial Technology and Genebank (IMTECH), Chandigarh. The IR spectra was recorded on the Bruker 12060280 FTIR spectrophotometer using $\mathrm{KBr}$ pellet method. The Bruker Avance II 400 NMR spectrometer was used for carried out the NMR spectroscopy $\left({ }^{1} \mathrm{H}\right.$ NMR and ${ }^{13} \mathrm{C}$ NMR), for the synthesized derivatives in deuterated DMSO solvent. The structures of the synthesized derivatives were confirmed by mass spectra, taken on the Advion expression CMS, USA mass spectrometer with APCI mode as the ion source.

\section{Synthetic procedure for indole diazenyl Schiff bases}

The $p$-aminoacetophenone $(0.01 \mathrm{~mol}, 1.35 \mathrm{~g})$ was dissolved in $10 \mathrm{ml}$ solution of $0.2 \mathrm{~N} \mathrm{HCl}$ followed by addition of $5 \mathrm{ml}$ solution of sodium nitrite $(0.01 \mathrm{~mol})$ at $0-5{ }^{\circ} \mathrm{C}$ to complete the diazotization process. The indole/5-nitroindole $(0.01 \mathrm{~mol})$ was solubilized in $20 \mathrm{ml}$ of acetic/propionic acid (8:2) mixture and cooled at 


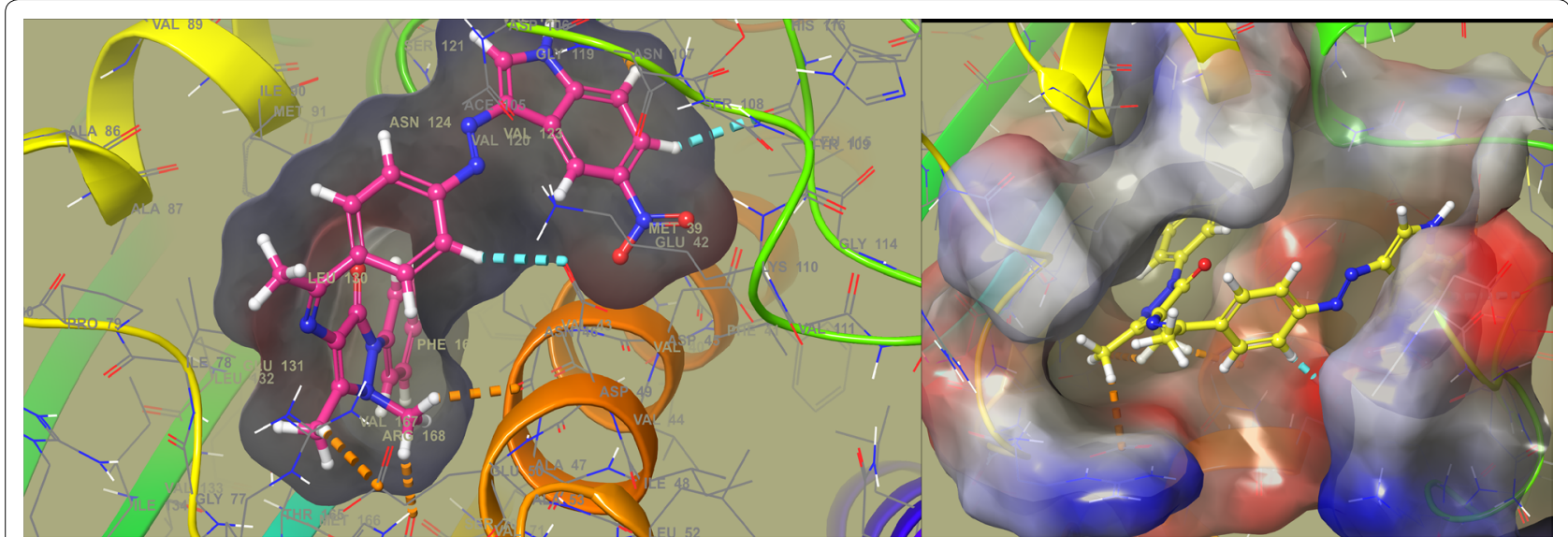

a

b

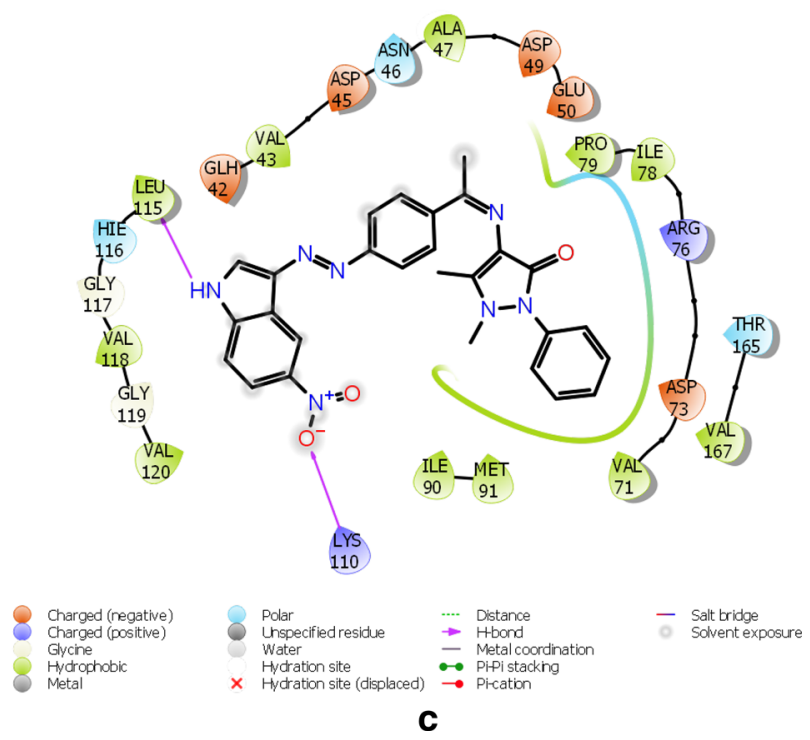

Fig. 4 a Best docked pose of DS-6 with GyrB (4KFG), b surface binding of DS-6 with 4KFG, c ligand Interaction diagram of DS-6 with 4KFG

$0{ }^{\circ} \mathrm{C}$. The diazotized solution was added to the indole derivative gradually at $0{ }^{\circ} \mathrm{C}$ over a period of $10-15 \mathrm{~min}$ followed by stirring for $1-2 \mathrm{~h}$ in the cold conditions. Afterwards saturated sodium carbonate solution (20$25 \mathrm{ml}$ ) was added to precipitate the azo dye $(\mathbf{1}, 2)$ with continuous stirring for further half an hour [38, 39]. The precipitated azo dye was filtered, vacuum dried and recrystallized from ethanol and used further for the synthesis of indole diazenyl Schiff bases. In $250 \mathrm{ml}$ round bottom flask, indole azo dye $(0.001 \mathrm{M})$ was refluxed with aromatic/heteroaromatic amine $(0.001 \mathrm{M})$ in the presence of ethanol and catalytic amount of acid on a heating mantle. The refluxing was continued for $7-8 \mathrm{~h}$ until the reaction completion was confirmed by TLC. The reaction volume was concentrated and kept at $7-8{ }^{\circ} \mathrm{C}$ for $24 \mathrm{~h}$ for the precipitation of Schiff bases. The synthesized Schiff bases were purified by recrystallization and column chromatography using ethyl acetate: methanol (70:30) on silica gel 100-200 mesh size [27, 40].

\section{Analytical data}

1-[4-[(E)-1H-Indol-3-ylazo]phenyl]ethanone (1): MF: $\mathrm{C}_{16} \mathrm{H}_{13} \mathrm{~N}_{3} \mathrm{O}$; 263.29; Maroon color; Yield: 92\%; mp: 90-95 ${ }^{\circ} \mathrm{C}$ : IR $\left(\mathrm{KBr}, \mathrm{cm}^{-1}\right) v_{\max }: 3217,2921,1668,1592$, 1460, 1424, 1358, 1266, 1215, 1169, 1053, 1014, 959, 837, 748, 624, 594, 446; ${ }^{1} \mathrm{H}$ NMR (400 MHz, DMSO-d $\left.{ }_{6}\right)$ $\delta: 11.96(\mathrm{~s}, 1 \mathrm{H},-\mathrm{NH}-$ of indole), $9.01(\mathrm{~s}, 1 \mathrm{H},-\mathrm{CH}(2)$ of indole), $8.16(\mathrm{~d}, J=2.4 \mathrm{~Hz}, 1 \mathrm{H},-\mathrm{CH}(4)$ of indole $), 8.01$ (d, $\left.J_{I}=8.8 \mathrm{~Hz}, 2 \mathrm{H}, \mathrm{ArH}\right), 7.51-7.76(\mathrm{~m}, 2 \mathrm{H},-\mathrm{CH}(6,7)$ of indole), $7.32(\mathrm{~d}, J=8.8 \mathrm{~Hz}, 2 \mathrm{H}, \mathrm{ArH}), 7.21-7.26(\mathrm{~m}, 1 \mathrm{H},-$ $\mathrm{CH}(5)$ of indole), $2.18\left(\mathrm{~s}, 3 \mathrm{H}, \mathrm{CH}_{3}\right) ;{ }^{13} \mathrm{C}$ NMR $(100 \mathrm{MHz}$, DMSO-d 6 ) $\delta: 198.2,148.8,140.1,138.7,133.7,128.5$, 124.8, 122.9, 117.6, 117.4, 116.7, 115.5, 113.4, 112.3, 26.2.

1-[4-[(E)-(5-Nitro-1H-indol-3-yl)azo]phenyl] ethanone (2): MF: $\mathrm{C}_{16} \mathrm{H}_{12} \mathrm{~N}_{4} \mathrm{O}_{3}$; 308.29; Orange color; Yield: 69\%; 


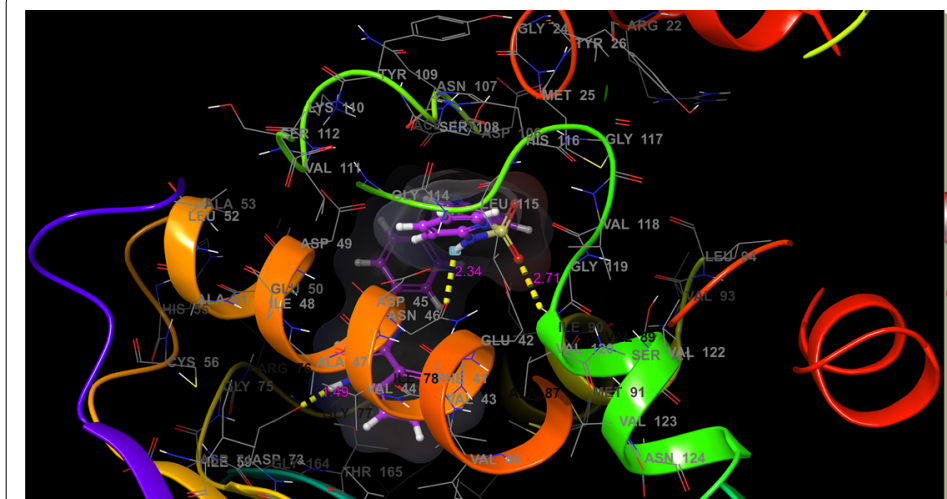

a

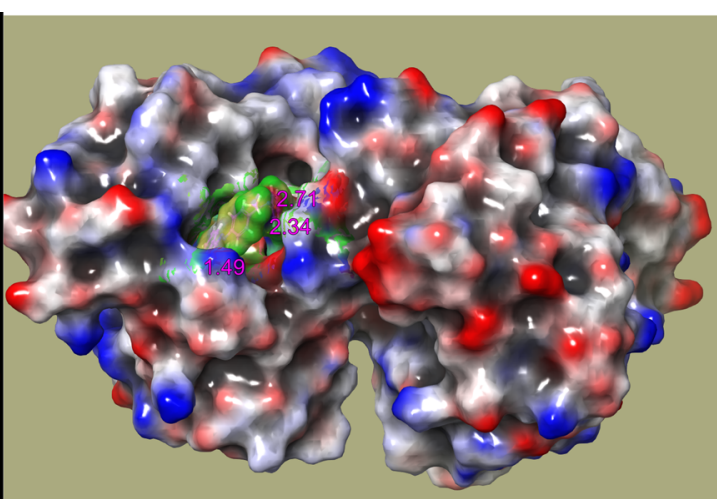

b

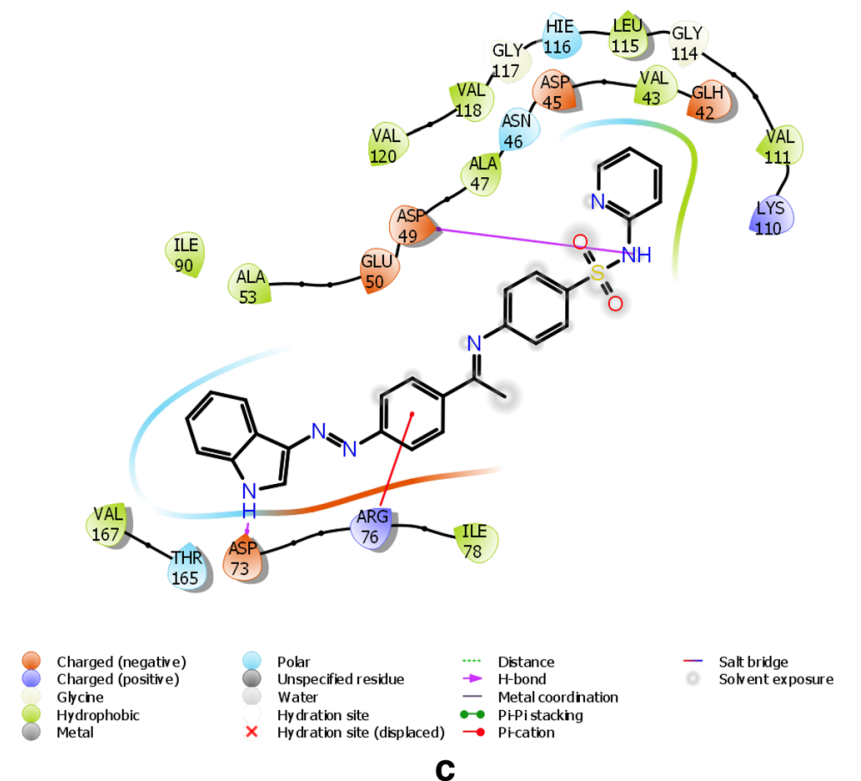

Fig. 5 a Best docked pose of DS-11 with GyrB (4KFG), b surface binding of DS-11 with 4KFG, $\mathbf{c}$ ligand interaction diagram of DS-11 with 4KFG

mp: $65-70{ }^{\circ} \mathrm{C}$; IR $\left(\mathrm{KBr}, \mathrm{cm}^{-1}\right) v_{\max }: 3328,2925,1707$, $1669,1617,1517,1468,1426,1329,1167,1108,1065,894$, 826, 780, 743, 682, 588, 540, 432; ${ }^{1} \mathrm{H}$ NMR $(400 \mathrm{MHz}$, DMSO- $\left.\mathrm{d}_{6}\right) \delta: 12.01$ (s, $1 \mathrm{H},-\mathrm{NH}-$ of indole), $9.97(\mathrm{~s}, 1 \mathrm{H}$, $-\mathrm{CH}(2)$ of indole), 8.35-8.47 (m, $1 \mathrm{H},-\mathrm{CH}(4)$ of indole), $8.22(\mathrm{~d}, J=2.4 \mathrm{~Hz}, 1 \mathrm{H},-\mathrm{CH}(7)$ of indole), 7.98 (dd, $J_{1}=8.8 \mathrm{~Hz}, J_{2}=2.4 \mathrm{~Hz}, 1 \mathrm{H},-\mathrm{CH}(6)$ of indole), 7.56-7.63 (m, 2H, ArH), 7.11 (d, J=8.8 Hz, 2H, ArH), 2.09 (s, 3H, $\left.\mathrm{CH}_{3}\right) ;{ }^{13} \mathrm{C}$ NMR (100 MHz, DMSO-d $\left.{ }_{6}\right) \delta: 198.6,162.9$, $141.0,140.8,138.81,133.8,128.5,124.8,122.8,117.5$, $117.4,116.7,115.1,113.2,112.3,26.3$.

(E)-N-(2-Furylmethyl)-1-[4-[(E)-1H-indol-3-ylazo] phenyl]ethanimine (DS-1): Dark Maroon; Yield: 75\%; $\mathrm{R}_{\mathrm{f}}=0.57$ (ethyl acetate/methanol 8:2); mp: $315-320{ }^{\circ} \mathrm{C}$; IR $\left(\mathrm{KBr}, \mathrm{cm}^{-1}\right) v_{\max }$ 3297, 3055, 2922, 1641, 1596, 1401, 1355, 1264, 1158, 1011, 958, 884, 837, 744, 593, 498, 431;
${ }^{1} \mathrm{H}$ NMR (400 MHz, DMSO-d 6 ) $\delta: 11.19$ (s, 1H, -NH- of indole), $9.02(\mathrm{~s}, 1 \mathrm{H},-\mathrm{CH}(2)$ of indole), $8.38(\mathrm{~d}, J=8.0 \mathrm{~Hz}$, $1 \mathrm{H},-\mathrm{CH}(4)$ of indole), $8.09(\mathrm{~d}, J=8.4 \mathrm{~Hz}, 2 \mathrm{H}, \mathrm{ArH})$, 7.8-8.02 (m, $1 \mathrm{H},-\mathrm{CH}(7)$ of indole $), 7.63(\mathrm{~d}, J=8.4 \mathrm{~Hz}$, $2 \mathrm{H}, \mathrm{ArH}), 7.36-7.59$ ( $\mathrm{m}, 2 \mathrm{H},-\mathrm{CH}(5,6)$ of indole), 7.02 (d, $J=7.2 \mathrm{~Hz}, 1 \mathrm{H},-\mathrm{CH}(5)$ of furan), $6.84(\mathrm{~d}, J=7.2 \mathrm{~Hz}$, $1 \mathrm{H},-\mathrm{CH}(4)$ of furan), $6.37(\mathrm{~d}, J=7.2 \mathrm{~Hz}, 1 \mathrm{H},-\mathrm{CH}(3)$ of furan), 4.23 (s, $\left.2 \mathrm{H}, \mathrm{CH}_{2}\right), 1.89\left(\mathrm{~s}, 3 \mathrm{H}, \mathrm{CH}_{3}\right) ;{ }^{13} \mathrm{C} \mathrm{NMR}$ $\left(100 \mathrm{MHz}, \mathrm{DMSO}-\mathrm{d}_{6}\right) \delta: 170.2,155.5,152.2,147.6,140.9$, $137.6,135.2,125.7,126.5,122.3,121.9,121.8,121.0$, 120.5, 117.3, 115.2, 109.1, 56.2, 23.5; APCI-MS m/z found for $\mathrm{C}_{21} \mathrm{H}_{18} \mathrm{~N}_{4} \mathrm{O}$ : $342.39\left(\mathrm{M}^{+}\right)$; Anal. calcd for $\mathrm{C}_{21} \mathrm{H}_{18} \mathrm{~N}_{4} \mathrm{O}$ : C 73.67, H 5.30, N 16.36, O 4.67 found C 73.69, H 5.35, N 16.39, O 4.65.

Ethyl 2-((Z)-(1-(4-((Z)-(1H-indol-3-yl)diazenyl) phenyl)ethylidene)amino)-4,5,6,7-tetrahydrobenzo[b] 


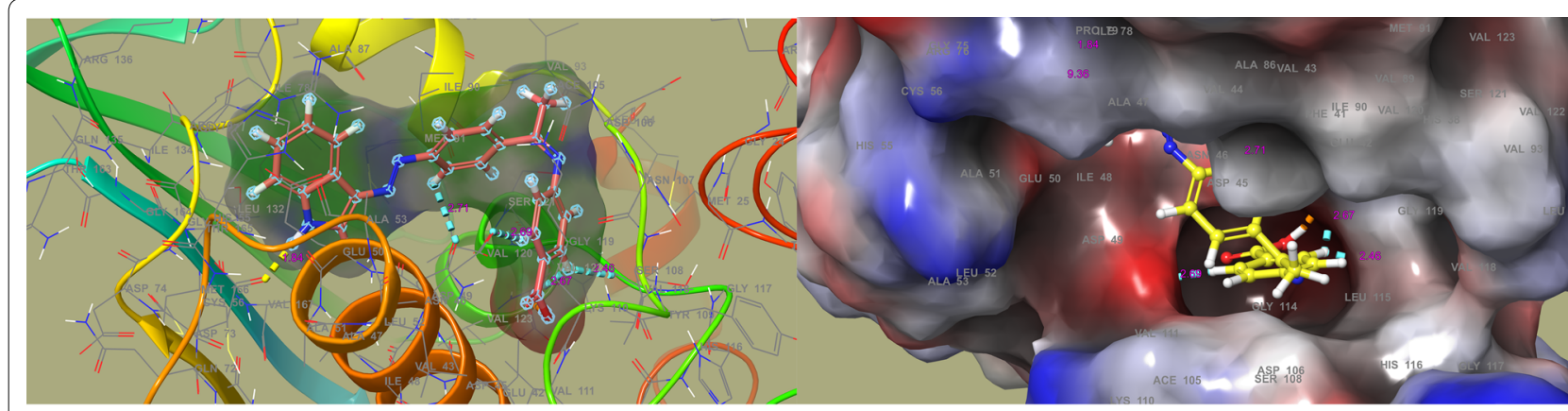

a

b

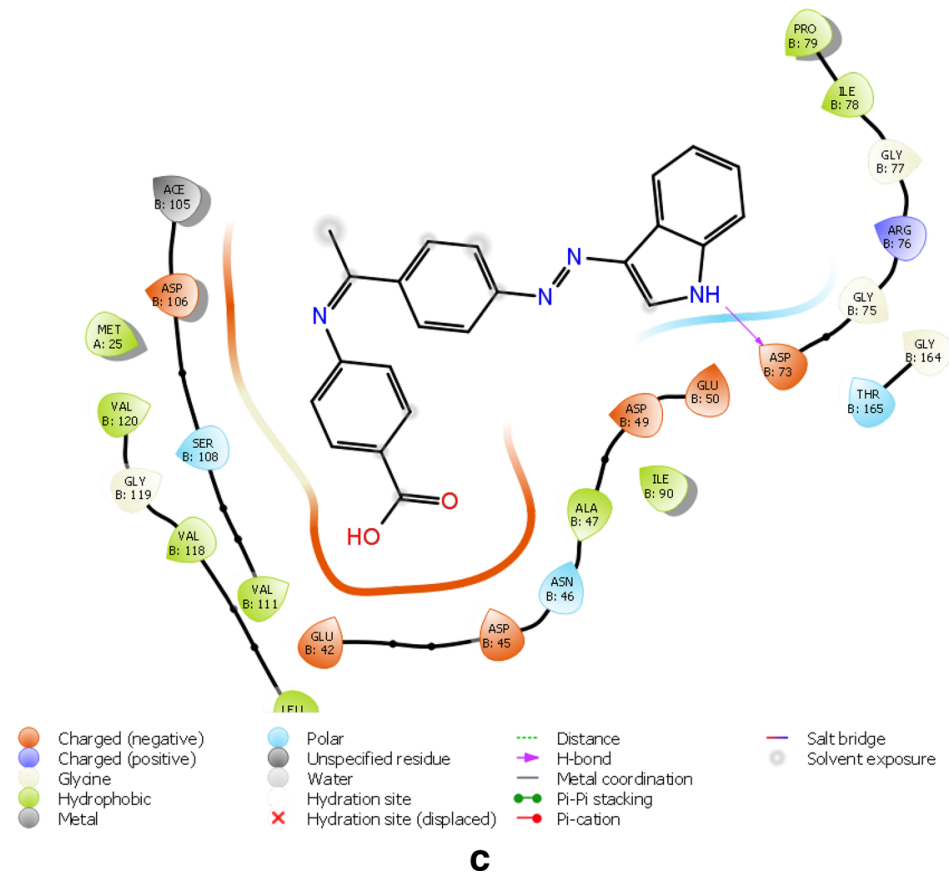

Fig. 6 a Best docked pose of DS-14 with GyrB (4KFG), b surface binding of DS-14 with 4KFG, c ligand interaction diagram of DS-14 with 4KFG

thiophene-3-carboxylate (DS-2): Dark Maroon; Yield: 79\%; mp: $260-265{ }^{\circ} \mathrm{C} ; \mathrm{R}_{\mathrm{f}}=0.49$ (ethyl acetate/methanol 8:2); IR $\left(\mathrm{KBr}, \mathrm{cm}^{-1}\right) v_{\max }$ : 3404, 3298, 3169, 2982, 2934, 2847, 1721, 1646, 1593, 1488, 1413, 1373, 1335, 1278, 1149, 1024, 967, 894, 836, 744, 601, 510, 469, 432; ${ }^{1} \mathrm{H}$ NMR (400 MHz, DMSO-d $\left.\mathrm{d}_{6}\right) \delta: 11.29(\mathrm{~s}, 1 \mathrm{H},-\mathrm{NH}-$ of indole), $8.92(\mathrm{~s}, 1 \mathrm{H},-\mathrm{CH}(2)$ of indole), 8.10 (d, $J=8.8 \mathrm{~Hz}, 2 \mathrm{H}, \mathrm{ArH}), 7.95$ (d, $J=8.8 \mathrm{~Hz}, 2 \mathrm{H}, \mathrm{ArH}), 7.41$ (d, $J=7.6 \mathrm{~Hz}, 1 \mathrm{H},-\mathrm{CH}(4)$ of indole), 7.25-7.35 (m, $1 \mathrm{H},-\mathrm{CH}(7)$ of indole), 7.04-7.09 $(\mathrm{m}, 1 \mathrm{H},-\mathrm{CH}(5)$ of indole), $6.84(\mathrm{~d}, J=4.0 \mathrm{~Hz}, 1 \mathrm{H},-\mathrm{CH}(6)$ of indole), 4.13 (q, $\left.J=9.6 \mathrm{~Hz}, 2 \mathrm{H},-\mathrm{OCH}_{2}\right), 2.74-2.82\left(\mathrm{~m}, 4 \mathrm{H}, \mathrm{CH}_{2}\right), 1.90(\mathrm{~s}$, $\left.3 \mathrm{H}, \mathrm{CH}_{3}\right), 1.44-1.84\left(\mathrm{~m}, 4 \mathrm{H}, \mathrm{CH}_{2}\right), 1.23(\mathrm{t}, J=9.6 \mathrm{~Hz}, 3 \mathrm{H}$, $\left.\mathrm{CH}_{3}\right) ;{ }^{13} \mathrm{C}$ NMR (100 MHz, DMSO-d 6 ) $\delta: 175.3,169.6$, $160.6,155.3,142.2,139.1,137.5,135.3,132.5,129.2$, $127.5,125.4,123.6,123.0,122.2,121.4,120.2,115.7,61.8$,
26.5, 26.3, 24.4, 23.6, 22.5, 14.3; APCI-MS $\mathrm{m} / \mathrm{z}$ found for $\mathrm{C}_{27} \mathrm{H}_{26} \mathrm{~N}_{4} \mathrm{O}_{2} \mathrm{~S}$ : $470.18\left(\mathrm{M}^{+}\right)$; Anal. calcd for $\mathrm{C}_{27} \mathrm{H}_{26} \mathrm{~N}_{4} \mathrm{O}_{2} \mathrm{~S}$ : C 68.91, H 5.57, N 11.91, O 6.80, S 6.81 found C 68.95, H $5.54, \mathrm{~N} 11.88$, O 6.82.

(Z)-5-(2-Chloro-4-nitrophenyl)-N-(1-(4-((Z)-(5-nitro$1 H$-indol-3-yl)diazenyl)phenyl) ethylidene)-1,3,4-thiadiazol-2-amine (DS-3): Orange; Yield: $68 \%$; mp: $155-160{ }^{\circ} \mathrm{C}$; $\mathrm{R}_{\mathrm{f}}=0.61$ (ethyl acetate/methanol 7:3); IR $\left(\mathrm{KBr}, \mathrm{cm}^{-1}\right)$ $v_{\max }: 3347,3107,2924,1707,1669,1617,1519,1467$, 1332, 1221, 1143, 1062, 963, 915, 827, 782, 740, 684, 656, 590, 535; ${ }^{1} \mathrm{H}$ NMR $\left(400 \mathrm{MHz}, \mathrm{DMSO}-\mathrm{d}_{6}\right) \delta: 12.65(\mathrm{~s}, 1 \mathrm{H}$, $-\mathrm{NH}$ - of indole), $9.37(\mathrm{~s}, 1 \mathrm{H},-\mathrm{CH}(2)$ of indole), 8.75 (d, $J=2.4 \mathrm{~Hz}, 1 \mathrm{H},-\mathrm{CH}(4)$ of indole $), 8.62(\mathrm{~s}, 1 \mathrm{H}, \mathrm{CH}-\mathrm{C}-$ $\mathrm{Cl}), 8.34\left(\mathrm{dd}, J_{1}=8.4 \mathrm{~Hz}, J_{2}=2.4 \mathrm{~Hz}, 1 \mathrm{H},-\mathrm{CH}=\mathrm{C}-\mathrm{NO}_{2}\right)$, $8.24\left(\mathrm{dd}, J_{1}=8.4 \mathrm{~Hz}, J_{2}=2.8 \mathrm{~Hz}, 1 \mathrm{H},-\mathrm{CH}(6)\right.$ of phenyl), $8.15\left(\mathrm{dd}, J_{1}=9.2 \mathrm{~Hz}, J_{2}=2.4 \mathrm{~Hz}, 1 \mathrm{H}, \mathrm{CH}(6)\right.$ of indole), 


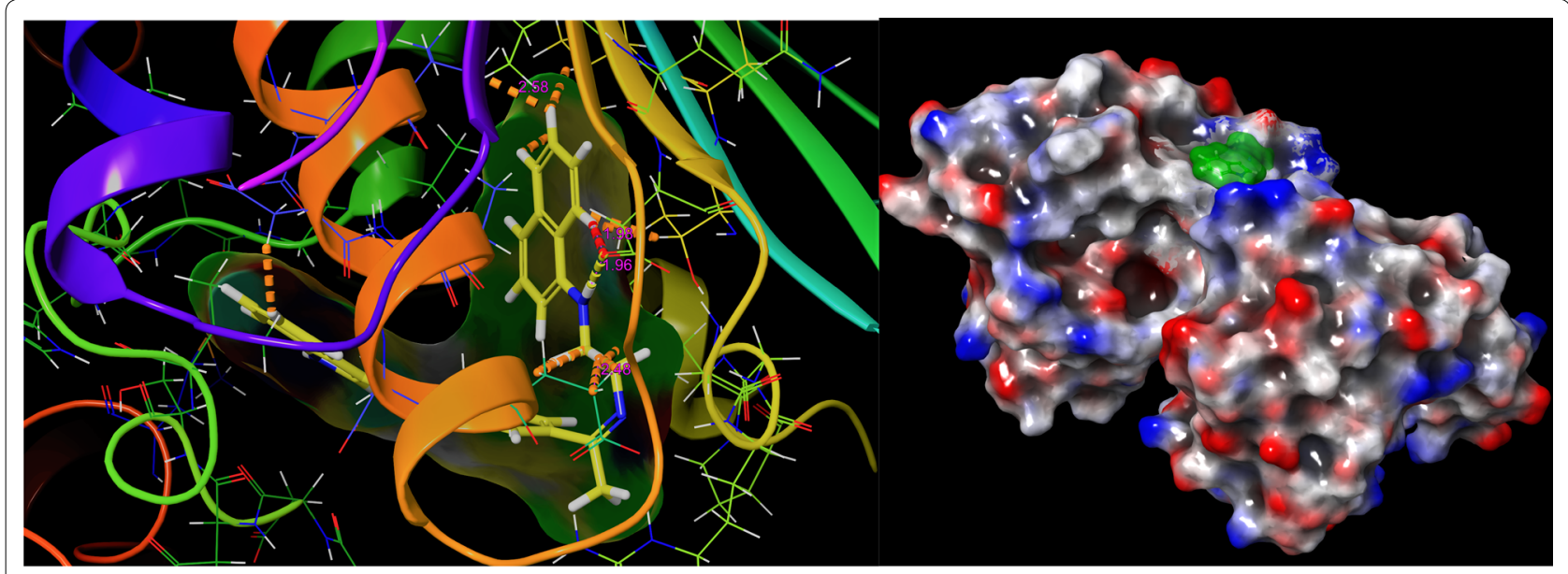

a

b

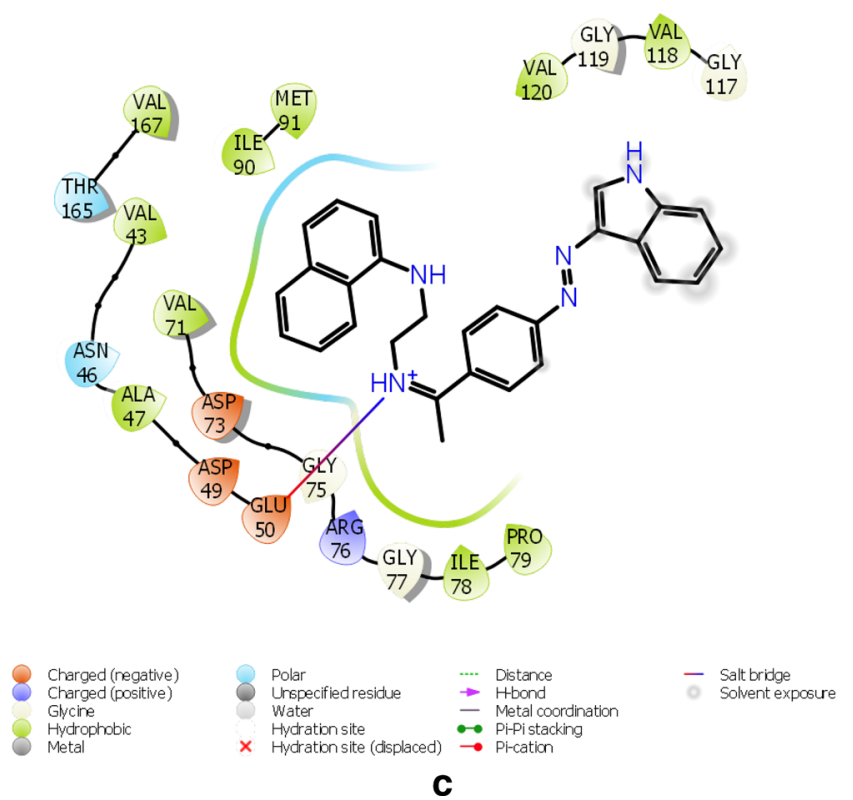

Fig. 7 a Best docked pose of DS-20 with GyrB (4KFG), b surface binding of DS-20 with 4KFG, $\mathbf{c}$ Ligand interaction diagram of DS-20 with 4KFG

$7.91(\mathrm{~d}, J=2.4 \mathrm{~Hz}, 1 \mathrm{H},-\mathrm{CH}(7)$ of indole), 7.55-7.75 (m, 4H, ArH), 2.07 (s, 3H, $\left.\mathrm{CH}_{3}\right) ;{ }^{13} \mathrm{C} \mathrm{NMR} \mathrm{(100} \mathrm{MHz,}$ DMSO- $\left.\mathrm{d}_{6}\right) \delta: 180.2,173.2,155.3,148.5,139.7,139.5$, $138.5,137.5,135.2,132.2,130.6,129.5,125.5,124.4$, $121.8,121.7,121.0,117.7,114.3,23.6$; APCI-MS m/z found for $\mathrm{C}_{24} \mathrm{H}_{15} \mathrm{ClN}_{8} \mathrm{O}_{4} \mathrm{~S}$ : $546.94\left(\mathrm{M}^{+}\right)$; Anal. calcd for $\mathrm{C}_{24} \mathrm{H}_{15} \mathrm{ClN}_{8} \mathrm{O}_{4} \mathrm{~S}: \mathrm{C}$ 52.70, $\mathrm{H}$ 2.76, $\mathrm{Cl}$ 6.48, N 20.49, O 11.70 S 5.86 found C 52.72, H 2.78, N 20.53, O 11.73.

(Z)-N-(1-(4-((Z)-(5-Nitro-1H-indol-3-yl)diazenyl) phenyl)ethylidene)-5-(4-nitrophenyl)-1,3,4-thiadiazol2-amine (DS-5): Orange; Yield: 57\%; mp: $160-165{ }^{\circ} \mathrm{C}$; $\mathrm{R}_{\mathrm{f}}=0.55$ (ethyl acetate/methanol 7:3); IR $\left(\mathrm{KBr}, \mathrm{cm}^{-1}\right)$ $v_{\max }: 3359,2923,2854,1831,1706,1617,1518,1467$,
1332, 1219, 1169, 1112, 1062, 929, 850, 823, 783, 742, 686, 593, 533, 449, 430; ${ }^{1} \mathrm{H}$ NMR (400 MHz, DMSO-d ${ }_{6}$ ) $\delta: 11.92(\mathrm{~s}, 1 \mathrm{H},-\mathrm{NH}-$ of indole), $9.89(\mathrm{~s}, 1 \mathrm{H},-\mathrm{CH}(2)$ of indole), $8.50(\mathrm{~s}, 1 \mathrm{H},-\mathrm{CH}(4)$ of indole), $8.32-8.42(\mathrm{~m}, 2 \mathrm{H}$, $\mathrm{ArH}), 8.14-8.15$ (m, 2H, ArH), 8.13 (d, J=2.4 Hz, 1H, $\mathrm{CH}(7)$ of indole), 7.87-7.94 (m, 2H, ArH), 7.45-7.56 (m, $2 \mathrm{H}, \mathrm{ArH}), 7.03$ (d, J=9.2 Hz, 1H, ArH), 2.02 (s, 3H, $\mathrm{CH}_{3}$ ); ${ }^{13} \mathrm{C}$ NMR (100 MHz, DMSO-d ${ }_{6}$ ) $\delta: 180.1,170.1,151.2$, $147.2,143.8,139.9,139.8,136.9,135.4,130.5,128.9$, 128.6, 124.6, 124.4, 122.6, 121.8, 120.9, 117.9, 114.3, 49.3, 23.6; APCI-MS m/z found for $\mathrm{C}_{24} \mathrm{H}_{16} \mathrm{~N}_{8} \mathrm{O}_{4} \mathrm{~S}: 512.5\left(\mathrm{M}^{+}\right)$; Anal. calcd for $\mathrm{C}_{24} \mathrm{H}_{16} \mathrm{~N}_{8} \mathrm{O}_{4} \mathrm{~S}$ : C 56.25, H 3.15, N 21.86, O 12.49, S 6.26 found C 56.28, H 3.14, N 21.89, O 12.52 . 
Table 5 The most active derivatives interaction with the key amino acid residues of the ATP binding pocket of GyrB subunit (PDB ID: 4KFG) from $E$. coli

\begin{tabular}{ll}
\hline Compound & Interacting residues at the active site \\
\hline DS-6 & Pro79, lle78, Gly77, Arg76, Asp73, lle90, Met91, Glu50, Asp49, Ala47, Asn46, Asp45, Val43, Glu42, Val120, Val118, His116, Leu \\
& 115, Val111, Ser108, Asp106 \\
DS-10 & Asn46, Ala47, Asp49, Glu50, Pro79, Ile78, Arg76, Asp73, Thr165, Ile 90, Arg76, Asp73, Thr165, Ile 90, Asp106, Asn 107, Ser108 \\
DS-11 & Val120, Gly119, Glu42, Val43, Asp45, Asn46, Ala47, Asp49, Glu50, Ser108, Asp73, Arg76 \\
DS-14 & Pro79, Ile78, Arg76, Asp73, Glu50, Asp49, Ala47, Asn46, Asp45, Glu42, Val111, Ser108, Asp106 \\
DS-16 & Pro79, lle78, Arg76, Asp73, Glu50, Asp49, Ala47, Asn46, Asp45, Glu42, Val111, Ser108, Asn107, Asp106 \\
DS-19 & Asp73, Val71, Glu50, Asp49, Ala47, Asn46, Asp45, Val43, Glu42, Leu115, His116, Val118, Gly119, Val120, Ser108, Asp106 \\
DS-20 & Pro79, Ile78, Gly77, Arg76, Asp73, Gln72, Val71, Glu50, Ala47, Asn46, Asp45, Val43, Glu42 \\
DS-21 & Pro79, Ile78, Arg76, Asp73, Glu50, Asp49, Asp73, Ala47, Asn46, Val120, Asp45, Val118 \\
CPR & Ile90, Val120, Leu132, Val167, Val43, Asn46, Ala47, Thr165, Val71, Asp73, Arg76, Ile78, Pro79 \\
NOV & Ile90, Ala53, Glu50, Asp49, Ala47, Asn46, Lys110, Thr165, Asp73, Arg76, Ile78, Pro79 \\
\hline
\end{tabular}

CPR ciprofloxacin, NOV novobiocin

Table 6 ADME properties of indole diazenyl Schiff bases (DS1-DS21) by Qikprop module of Schrodinger

\begin{tabular}{llllllllll}
\hline Comp. & MW & Donor HB & Acceptor HB & (Log Po/w) & (QPlogS) & (QPPMDCK) & (QPlogBB) & Rule of Five & \% Oral absorption \\
\hline DS-1 & 342.399 & 1.00 & 3.50 & 4.888 & -5.776 & 864.120 & -0.617 & 0 & 100 \\
DS-2 & 470.588 & 1.00 & 5.00 & 6.083 & -7.814 & 564.131 & -1.016 & 1 & 100 \\
DS-3 & 546.947 & 1.00 & 7.00 & 4.160 & -7.620 & 8.456 & -3.210 & 2 & 41.89 \\
DS-5 & 512.502 & 1.00 & 7.00 & 3.729 & -7.238 & 3.533 & -3.464 & 2 & 38.89 \\
DS-6 & 493.524 & 1.00 & 8.00 & 4.595 & -7.214 & 71.086 & -1.885 & 0 & 93.59 \\
DS-7 & 374.462 & 1.00 & 5.00 & 4.211 & -5.864 & 343.064 & -1.110 & 0 & 100 \\
DS-10 & 452.299 & 1.00 & 4.00 & 5.219 & -7.051 & 386.353 & -1.300 & 1 & 85.55 \\
DS-11 & 494.570 & 2.00 & 8.500 & 4.422 & -6.748 & 85.060 & -1.945 & 0 & 93.76 \\
DS-13 & 417.854 & 1.00 & 4.00 & 4.320 & -4.299 & 493.198 & -0.688 & 0 & 100 \\
DS-14 & 382.421 & 2.00 & 5.00 & 3.949 & -3.722 & 47.744 & -0.975 & 0 & 85.21 \\
DS-15 & 504.519 & 2.00 & 9.00 & 2.377 & -3.734 & 13.240 & -2.063 & 2 & 42.512 \\
DS-16 & 401.399 & 1.00 & 4.00 & 4.627 & -6.447 & 148.752 & -1.521 & 0 & 94.824 \\
DS-17 & 340.387 & 1.00 & 5.00 & 3.227 & -3.492 & 353.077 & -0.687 & 0 & 100.000 \\
DS-19 & 495.558 & 2.00 & 9.50 & 3.858 & -6.342 & 65.284 & -2.073 & 0 & 88.565 \\
DS-20 & 431.539 & 2.00 & 4.00 & 6.504 & -7.473 & 997.487 & -0.729 & 1 & 100.00 \\
DS-21 & 440.478 & 1.00 & 5.50 & 4.377 & -6.667 & 76.004 & -1.861 & 0 & 89.828 \\
CFT & 455.460 & 3.25 & 12.95 & 0.586 & -7.254 & 1.758 & -3.778 & 1 & 21.057 \\
CPR & 331.346 & 1.00 & 6.00 & 0.280 & -4.829 & 10.642 & -0.643 & 0 & 48.759 \\
NOV & 612.632 & 5.25 & 13.15 & 2.612 & -3.791 & 3.490 & -4.055 & 3 \\
\hline CFT & & & & & 21.432
\end{tabular}

CFT cefotaxime, CPR ciprofloxacin, NOV novobiocin, $M W$ molecular weight, DonorHB hydrogen bond donor, $A$ cceptorHB hydrogen bond acceptor, $P_{O / W}$ partition coefficient in oil and water, QPlogS aqueous solubility, QPPMDCK apparent MDCK cell permeability, QPlogBB brain/blood partition coefficient

1,5-Dimethyl-4-((Z)-(1-(4-((Z)-(5-nitro-1H-indol3-yl)diazenyl)phenyl)ethylidene) amino)-2-phenyl-1Hpyrazol-3(2H)-one (DS-6): Dark Yellow; Yield: 64\%; $\mathrm{R}_{\mathrm{f}}=0.51$ (ethyl acetate/methanol 8:2); mp: 170-175 ${ }^{\circ} \mathrm{C}$; IR $\left(\mathrm{KBr}, \mathrm{cm}^{-1}\right) v_{\max }: 3348,3124,2924,1705,1619,1518$, 1468, 1425, 1329, 1252, 1167, 1112, 1062, 927, 895, 823, 785, 741, 688, 656, 591, 538, 448; ${ }^{1} \mathrm{H}$ NMR $(400 \mathrm{MHz}$, DMSO- $\left.\mathrm{d}_{6}\right) \delta$ : $11.99(\mathrm{~s}, 1 \mathrm{H},-\mathrm{NH}$ of indole), $9.97(\mathrm{~s}, 1 \mathrm{H}$, $-\mathrm{CH}(2)$ of indole), $8.57(\mathrm{~d}, J=2.0 \mathrm{~Hz}, 1 \mathrm{H},-\mathrm{CH}(4)$ of indole), $8.43\left(\mathrm{dd}, J_{1}=9.2 \mathrm{~Hz}, J_{2}=2.4 \mathrm{~Hz}, 1 \mathrm{H},-\mathrm{CH}(6)\right.$ of indole), $8.37(\mathrm{~d}, J=2.4 \mathrm{~Hz}, 1 \mathrm{H},-\mathrm{CH}(7)$ of indole), 8.22 $(\mathrm{d}, J=8.4 \mathrm{~Hz}, 2 \mathrm{H}, \mathrm{ArH}), 7.98\left(\mathrm{dd}, J_{1}=9.2 \mathrm{~Hz}, J_{2}=2.4 \mathrm{~Hz}\right.$, $1 \mathrm{H}, \mathrm{ArH}), 7.58-7.63$ (m, 2H, ArH), 7.11 (d, J=9.2 Hz, $1 \mathrm{H}, \mathrm{ArH}), 6.73-6.74(\mathrm{~m}, 1 \mathrm{H}, \mathrm{ArH}), 2.11$ (s, 3H, $\left.\mathrm{CH}_{3}\right)$, 1.98 (s, 3H, $\left.\mathrm{CH}_{3}\right), 1.92\left(\mathrm{~s}, 3 \mathrm{H}, \mathrm{CH}_{3}\right) ;{ }^{13} \mathrm{C} \mathrm{NMR}(100 \mathrm{MHz}$, DMSO- $\left.\mathrm{d}_{6}\right) \delta: 162.2,161.9,151.2,147.5,139.9,139.8$, $139.4,135.5,132.1,130.5,129.1,126.8,126.4,124.6$, $124.3,124.2,121.9,120.9,118.1,114.3,36.2,22.6,13.9$; 
APCI-MS m/z found for $\mathrm{C}_{27} \mathrm{H}_{23} \mathrm{~N}_{7} \mathrm{O}_{3}: 493.52\left(\mathrm{M}^{+}\right)$; Anal. calcd for $\mathrm{C}_{27} \mathrm{H}_{23} \mathrm{~N}_{7} \mathrm{O}_{3}$ : C 65.71, H 4.70, N 19.87, O 9.73 found $\mathrm{C} 65.75, \mathrm{H} 4.67 \mathrm{~N} 19.89$, O 9.69.

(Z)-N-(1-(4-((Z)-(1H-Indol-3-yl)diazenyl)phenyl) ethylidene)-5-ethyl-1,3,4-thiadiazol-2-amine (DS-7): Dark Maroon; Yield: $70 \%$; mp: $145-150{ }^{\circ} \mathrm{C} ; \mathrm{R}_{\mathrm{f}}=0.47$ (ethyl acetate/methanol 7:3); IR $\left(\mathrm{KBr}, \mathrm{cm}^{-1}\right) v_{\max }$ : 3262, 3050, 2977, 2921, 2751, 1684, 1588, 1491, 1455, 1419, 1371, 1304, 1268, 1197, 1107, 1013, 960, 922, 834, 801, 745, 701, 597, 458, 429; ${ }^{1} \mathrm{H}$ NMR (400 MHz, DMSO-d $\left.{ }_{6}\right)$ $\delta: 12.28(\mathrm{~s}, 1 \mathrm{H},-\mathrm{NH}$ of indole), 7.04-7.91 (m, 8H, ArH), $2.96\left(\mathrm{q}, J=7.6 \mathrm{~Hz}, 2 \mathrm{H},-\mathrm{CH}_{2}\right), 1.89\left(\mathrm{~s}, 3 \mathrm{H},-\mathrm{CH}_{3}\right) 1.27(\mathrm{t}$, $\left.J=7.6 \mathrm{~Hz}, 3 \mathrm{H},-\mathrm{CH}_{3}\right) ;{ }^{13} \mathrm{C}$ NMR $\left(100 \mathrm{MHz}, \mathrm{DMSO}-\mathrm{d}_{6}\right)$ $\delta: 175.3,169.2,164.4,154.0,138.5,136.2,135.3,132.0$, 130.1, 128.8, 126.1, 125.2, 123.1, 121.6, 113.2, 23.9, 23.9, 13.1; APCI-MS m/z found for $\mathrm{C}_{20} \mathrm{H}_{18} \mathrm{~N}_{6} \mathrm{~S}: 374.46\left(\mathrm{M}^{+}\right)$; Anal. calcd for $\mathrm{C}_{20} \mathrm{H}_{18} \mathrm{~N}_{6} \mathrm{~S}$ : C 64.15, H 4.85, N 22.44, S 8.56 found C 64.14, H 4.81 N 22.47, O 8.59.

(Z)-2,5-Dichloro- $N$-(1-(4-((Z)-(5-nitro- $1 H$-indol-3-yl) diazenyl)phenyl)ethylidene)aniline (DS-10): Orange; Yield: $72 \% \mathrm{mp}: 210-215{ }^{\circ} \mathrm{C} ; \mathrm{R}_{\mathrm{f}}=0.64$ (ethyl acetate/ methanol 7:3); IR (KBr, $\left.\mathrm{cm}^{-1}\right) v_{\max }$ : 3347, 2923, 2854, $1704,1619,1517,1468,1328,1252,1167,1113,1062$, 927, 895, 823, 785, 740, 687, 656, 590, 536, 449; ${ }^{1} \mathrm{H}$ NMR (400 MHz, DMSO-d $\left.\mathrm{d}_{6}\right) \delta: 11.99(\mathrm{~s}, 1 \mathrm{H},-\mathrm{NH}$ of indole), $9.97\left(\mathrm{~s}, 1 \mathrm{H},-\mathrm{CH}(2)\right.$ of indole), $8.43\left(\mathrm{dd}, J_{1}=9.2 \mathrm{~Hz}\right.$, $J_{2}=2.4 \mathrm{~Hz}, 1 \mathrm{H},-\mathrm{CH}(6)$ of indole $), 8.37(\mathrm{~d}, J=2.4 \mathrm{~Hz}$, $1 \mathrm{H},-\mathrm{CH}(7)$ of indole), $8.22(\mathrm{~d}, J=2.4 \mathrm{~Hz}, 1 \mathrm{H},-\mathrm{CH}(4)$ of indole), $7.98\left(\mathrm{dd}, J_{1}=9.2 \mathrm{~Hz}, J_{2}=2.4 \mathrm{~Hz}, 1 \mathrm{H},-\mathrm{CH}=\mathrm{C}-\right.$ Cl), 7.58-7.63 (m, 2H, ArH), $7.18(\mathrm{~d}, J=8.4 \mathrm{~Hz}, 2 \mathrm{H}$, $\mathrm{ArH}), 7.12(\mathrm{~d}, J=9.2 \mathrm{~Hz}, 1 \mathrm{H}, \mathrm{ArH}), 6.81(\mathrm{~d}, J=2.4 \mathrm{~Hz}$, $1 \mathrm{H}, \mathrm{ArH}), 1.91\left(\mathrm{~s}, 3 \mathrm{H}, \mathrm{CH}_{3}\right) ;{ }^{13} \mathrm{C}$ NMR $(100 \mathrm{MHz}$, DMSO- $\left.\mathrm{d}_{6}\right) \delta: 169.6,158.7,149.2,140.2,138.6,138.0$, $135.2,132.7,130.6,129.7,128.6,128.8,127.7,126.6$, 124.2, 123.2, 122.6, 121.6, 119.5, 115.3, 23.2; APCI-MS $\mathrm{m} / \mathrm{z}$ found for $\mathrm{C}_{22} \mathrm{H}_{15} \mathrm{Cl}_{2} \mathrm{~N}_{5} \mathrm{O}_{2}: 452.3\left(\mathrm{M}^{+}\right)$; Anal. calcd for $\mathrm{C}_{22} \mathrm{H}_{15} \mathrm{Cl}_{2} \mathrm{~N}_{5} \mathrm{O}_{2}$ : C 58.42, $\mathrm{H} 3.34 \mathrm{Cl} 15.68, \mathrm{~N}$ 15.48, O 7.07 found $\mathrm{C} 58.45, \mathrm{H} 3.37 \mathrm{~N}$ 15.51, O 7.06.

4-((Z)-(1-(4-((Z)-(1H-Indol-3-yl)diazenyl)phenyl)ethylidene)amino)- $N$-(pyridin-2-yl)benzenesulfonamide (DS-11): Maroon; Yield: $68 \% \mathrm{mp}: 135-140{ }^{\circ} \mathrm{C} ; \mathrm{R}_{\mathrm{f}}=0.57$ (ethyl acetate/methanol 7:3); IR (KBr, $\left.\mathrm{cm}^{-1}\right) v_{\text {max }}$ : 3221, 3055, 2924, 1677, 1623, 1593, 1530, 1495, 1459, 1386, 1331, 1245, 1130, 1083, 1007, 956, 830, 747, 676, 612, 564, 451; ${ }^{1} \mathrm{H}$ NMR (400 MHz, DMSO-d $\left.\mathrm{d}_{6}\right) \delta: 11.84(\mathrm{~s}, 1 \mathrm{H},-$ $\mathrm{NH}$ of indole), $10.92(\mathrm{~s}, 1 \mathrm{H},-\mathrm{CH}(2)$ of indole), 8.08 (d, $J=4.0 \mathrm{~Hz}, 2 \mathrm{H}, \mathrm{ArH}), 7.60-7.65$ (m, 3H, ArH), 7.48-7.52 (m, 3H, ArH), 7.05 (d, $J=8.4 \mathrm{~Hz}, 2 \mathrm{H}, \mathrm{ArH}), 6.98-7.10$ $(\mathrm{m}, 2 \mathrm{H},-\mathrm{CH}(5,6)$ of indole), 6.87-6.90 $(\mathrm{m}, 2 \mathrm{H}), 6.52-$ $6.55(\mathrm{~m}, 2 \mathrm{H}, \mathrm{ArH}), 5.91-5.98\left(\mathrm{~m}, 1 \mathrm{H},-\mathrm{SO}_{2} \mathrm{NH}\right), 1.89$ $\left(\mathrm{s}, 3 \mathrm{H}, \mathrm{CH}_{3}\right) ;{ }^{13} \mathrm{C}$ NMR $\left(100 \mathrm{MHz}\right.$, DMSO-d $\left.\mathrm{d}_{6}\right) \delta: 169.8$, $156.1,155.2$, 148.4, 137.6, 137.6, 136.5, 135.4, 133.2, $130.0,128.3,127.8,123.6,123.1,123.1,121.8,120.9$,
120.1, 117.8, 114.5, 112.5, 22.8; APCI-MS $\mathrm{m} / \mathrm{z}$ found for $\mathrm{C}_{27} \mathrm{H}_{22} \mathrm{~N}_{6} \mathrm{O}_{2} \mathrm{~S}: 494.56\left(\mathrm{M}^{+}\right)$; Anal. calcd for $\mathrm{C}_{27} \mathrm{H}_{22} \mathrm{~N}_{6} \mathrm{O}_{2} \mathrm{~S}$ : C 65.57, H 4.48, N 16.99, O 6.47 S 6.48 found C 65.59, H $4.49 \mathrm{~N} 16.96, \mathrm{O} 6.51$.

(Z)-N-(1-(4-((Z)-(1H-Indol-3-yl)diazenyl)phenyl) ethylidene)-4-chloro-2-nitroaniline (DS-13): Maroon; Yield: 65\%; $\mathrm{R}_{\mathrm{f}}=0.49$ (ethyl acetate/methanol 8:2); IR (KBr, $\left.\mathrm{cm}^{-1}\right) v_{\text {max }}: 3474,3355,3096,3056,2963,2922,2857$, $1632,1596,1563,1502,1455,1406,1339,1246,1117$, 1013, 959, 887, 817, 744, 645, 591, 521, 466, 416; ${ }^{1} \mathrm{H}$ NMR $\left(400 \mathrm{MHz}, \mathrm{DMSO}-\mathrm{d}_{6}\right) \delta: 11.99(\mathrm{~s}, 1 \mathrm{H},-\mathrm{NH}$ of indole), $9.97\left(\mathrm{~s}, 1 \mathrm{H},-\mathrm{CH}(2)\right.$ of indole), $8.43\left(\mathrm{dd}, J_{1}=9.2 \mathrm{~Hz}\right.$, $\left.J_{2}=2.4 \mathrm{~Hz}, 1 \mathrm{H},-\mathrm{CH}-\mathrm{C}-\mathrm{Cl}\right), 8.37(\mathrm{~d}, J=2.0 \mathrm{~Hz}, 1 \mathrm{H}$, $-\mathrm{CH}(4)$ of indole), $8.22(\mathrm{~d}, J=2.4 \mathrm{~Hz}, 1 \mathrm{H},-\mathrm{CH}(7)$ of indole), 7.98 (dd, $\left.J_{1}=9.2 \mathrm{~Hz}, J_{2}=2.4 \mathrm{~Hz}, 1 \mathrm{H}, \mathrm{ArH}\right), 7.58$ $7.63(\mathrm{~m}, 2 \mathrm{H}, \mathrm{ArH}), 7.18(\mathrm{~d}, J=8.4 \mathrm{~Hz}, 2 \mathrm{H}, \mathrm{ArH}), 7.12$ (d, $J=9.2 \mathrm{~Hz}, 1 \mathrm{H}, \mathrm{ArH}), 6.81(\mathrm{~d}, J=2.4 \mathrm{~Hz}, 1 \mathrm{H},-\mathrm{CH}(5)$ of indole), $6.53\left(\mathrm{dd}, J_{1}=8.4 \mathrm{~Hz}, J_{2}=2.4 \mathrm{~Hz},-\mathrm{CH}(6)\right.$ of indole), 1.91 (s, 3H, $\left.\mathrm{CH}_{3}\right) ;{ }^{13} \mathrm{C}$ NMR (100 MHz, DMSO$\left.\mathrm{d}_{6}\right) \delta: 169.3,158.3,149.3,145.8,140.7,136.5,135.3,135.1$, 134.2, 132.4, 131.2, 129.6, 127.5, 126.5, 125.1, 122.5, 121.7, 119.3, 115.4; APCI-MS m/z found for $\mathrm{C}_{22} \mathrm{H}_{16} \mathrm{ClN}_{5} \mathrm{O}_{2}$ : 417.85 $\left(\mathrm{M}^{+}\right)$; Anal. calcd for $\mathrm{C}_{22} \mathrm{H}_{16} \mathrm{ClN}_{5} \mathrm{O}_{2}: \mathrm{C} 63.24, \mathrm{H}$ $3.86 \mathrm{Cl} 8.48, \mathrm{~N} 16.76$, O 7.66 found $\mathrm{C} 63.27, \mathrm{H} 3.89 \mathrm{~N}$ 16.79, O 7.68 .

4-((Z)-(1-(4-((Z)-(1H-Indol-3-yl)diazenyl)phenyl)ethylidene)amino)benzoic acid (DS-14): Maroon; Yield: 74\%; $\mathrm{mp}: 205-210{ }^{\circ} \mathrm{C} ; \mathrm{R}_{\mathrm{f}}=0.71$ (ethyl acetate/methanol 8:2); IR (KBr, $\left.\mathrm{cm}^{-1}\right) v_{\max }$ : 3391, 2924, 1676, 1601, 1529, 1458, 1381, 1249, 1172, 1108, 1043, 1014, 962, 746, 604, 456, 416; ${ }^{1} \mathrm{H}$ NMR $\left(400 \mathrm{MHz}, \mathrm{DMSO}-\mathrm{d}_{6}\right) \delta: 11.14(\mathrm{~s}, 1 \mathrm{H}$, $-\mathrm{NH}$ - of indole), 10.24 (s, $1 \mathrm{H},-\mathrm{COOH}), 9.12(\mathrm{~s}, 1 \mathrm{H},-$ $\mathrm{CH}(2)$ of indole), 7.87 (d, $J=8.8 \mathrm{~Hz}, 2 \mathrm{H}, \mathrm{ArH}), 7.67$ (d, $J=7.6 \mathrm{~Hz}, 1 \mathrm{H},-\mathrm{CH}(4)$ of indole), $7.37(\mathrm{~d}, J=8.0 \mathrm{~Hz}, 2 \mathrm{H}$, ArH), 7.14-7.28 (m, 2H, ArH), 7.01-7.05 (m, 2H, ArH), 6.78-6.89 (m, 2H, $-\mathrm{CH}(5,6)$ of indole), $1.97\left(\mathrm{~s}, 3 \mathrm{H}, \mathrm{CH}_{3}\right)$; ${ }^{13} \mathrm{C}$ NMR (100 MHz, DMSO-d ${ }_{6}$ ) $\delta: 173.9,169.5,155.3$, $152.4,140.3,138.2,136.9,135.4,133.0,129.2,128.1$, $126.7,123.2,122.3,120.9,119.4,118.5,115.2$; APCI-MS $\mathrm{m} / \mathrm{z}$ found for $\mathrm{C}_{23} \mathrm{H}_{18} \mathrm{~N}_{4} \mathrm{O}_{2}: 382.41\left(\mathrm{M}^{+}\right)$; Anal. calcd for $\mathrm{C}_{23} \mathrm{H}_{18} \mathrm{~N}_{4} \mathrm{O}_{2}$ : C 72.24, H 4.74, N 14.65, O 8.37 found $\mathrm{C}$ 72.26, H $4.78 \mathrm{~N} 14.61$, O 8.41.

$N-((4-((\mathrm{Z})-(1-(4-((\mathrm{Z})-(5-\mathrm{Nitro}-1 H$-indol-3-yl) diazenyl)phenyl)ethylidene)amino)phenyl) sulfonyl)acetamide (DS-15): Dark Maroon color; Yield: 64\%; mp: 110-115 ${ }^{\circ} \mathrm{C} ; \mathrm{R}_{\mathrm{f}}=0.64$ (ethyl acetate/methanol 8:2); IR $\left(\mathrm{KBr}, \mathrm{cm}^{-1}\right) v_{\text {max }}: 1685,1620,1509,1512,1458,1419$, $1373,1319,1242,1188,1130,1067,1033,829,740,686$, 624, 547; ${ }^{1} \mathrm{H}$ NMR (400 MHz, DMSO-d 6 ) $\delta: 11.96$ (s, $1 \mathrm{H},-\mathrm{NH}-$ of indole), 9.93 (s, $1 \mathrm{H},-\mathrm{CH}(2)$ of indole), $8.56\left(\mathrm{~s}, 1 \mathrm{H},-\mathrm{NH}\right.$ - of sulfonamide), $8.41\left(\mathrm{dd}, J_{1}=9.2 \mathrm{~Hz}\right.$, $J_{2}=2.4 \mathrm{~Hz}, 1 \mathrm{H},-\mathrm{CH}(6)$ of indole), $8.35(\mathrm{~d}, J=2.8 \mathrm{~Hz}$, $1 \mathrm{H},-\mathrm{CH}(4)$ of indole), $8.21(\mathrm{~d}, J=2.0 \mathrm{~Hz}, 1 \mathrm{H},-\mathrm{CH}(7)$ 
of indole), $7.96\left(\mathrm{dd}, J_{1}=9.2 \mathrm{~Hz}, J_{2}=2.4 \mathrm{~Hz}, 2 \mathrm{H}, \operatorname{ArH}\right)$, 7.49-7.59 (m, 2H, ArH), $7.10(\mathrm{~d}, J=9.2 \mathrm{~Hz}, 2 \mathrm{H}, \mathrm{ArH})$, 6.58-6.98 (m, 2H, ArH), $1.89\left(\mathrm{~s}, 3 \mathrm{H}, \mathrm{CH}_{3}\right), 1.85(\mathrm{~s}, 3 \mathrm{H}$, $\left.\mathrm{COCH}_{3}\right) ;{ }^{13} \mathrm{C}$ NMR (100 MHz, DMSO-d 6 ) $\delta: 173.9,160.2$, $158.3,143.1,140.2,135.1,130.3,129.2,126.6,125.2$, 123.6, 122.7, 120.4, 116.5, 23.2; APCI-MS $\mathrm{m} / \mathrm{z}$ found for $\mathrm{C}_{24} \mathrm{H}_{20} \mathrm{~N}_{6} \mathrm{O}_{5} \mathrm{~S}$ : $504.51\left(\mathrm{M}^{+}\right)$; Anal. calcd for $\mathrm{C}_{24} \mathrm{H}_{20} \mathrm{~N}_{6} \mathrm{O}_{5} \mathrm{~S}$ : C 57.14, H 4.00 Cl12.83, N 16.66, O 15.86, S 6.36 found C 57.17, H 4.03 N 16.68, O 15.81.

(Z)-4-Fluoro- $N$-(1-(4-((Z)-(5-nitro-1H-indol-3-yl)diazenyl)phenyl)ethylidene)aniline (DS-16): Dark Orange; Yield: $63 \%$; mp: $150-152{ }^{\circ} \mathrm{C} ; \mathrm{R}_{\mathrm{f}}=0.61$ (ethyl acetate/ methanol 8:2); IR (KBr, $\left.\mathrm{cm}^{-1}\right) v_{\max }: 3398,3056,2923$, 1612, 1596, 1456, 1426, 1338, 1269, 1154, 1013, 962, 924, 883, 816, 743, 596, 449; ${ }^{1} \mathrm{H}$ NMR (400 MHz, DMSO-d 6 ) $\delta: 11.96(\mathrm{~s}, 1 \mathrm{H},-\mathrm{NH}-$ of indole), $9.82(\mathrm{~s}, 1 \mathrm{H},-\mathrm{CH}(2)$ of indole), $8.56\left(\mathrm{~s}, 1 \mathrm{H}\right.$, indole), $8.41\left(\mathrm{dd}, J_{1}=9.2 \mathrm{~Hz}\right.$, $\left.J_{2}=2.4 \mathrm{~Hz}, 2 \mathrm{H}, \mathrm{ArH}\right), 8.35(\mathrm{~d}, J=2.4 \mathrm{~Hz}, 1 \mathrm{H}), 8.20(\mathrm{~d}$, $J=2.4 \mathrm{~Hz}, 1 \mathrm{H}$, indole), 8.11 (d, $J=7.6 \mathrm{~Hz}, 1 \mathrm{H}, \mathrm{ArH}), 7.95$ (dd, $\left.J_{1}=9.2 \mathrm{~Hz}, J_{2}=2.4 \mathrm{~Hz}, 2 \mathrm{H}, \mathrm{ArH}\right), 7.53-7.59(\mathrm{~m}, 2 \mathrm{H}$, $\mathrm{ArH}), 7.11(\mathrm{~d}, J=9.2 \mathrm{~Hz}, 1 \mathrm{H}, \mathrm{ArH}), 1.89\left(\mathrm{~s}, 3 \mathrm{H}, \mathrm{CH}_{3}\right) ;{ }^{13} \mathrm{C}$ NMR (100 MHz, DMSO-d $\left.{ }_{6}\right)$ \&: 169.7 166.3, 163.2, 156.4, $148.2,145.8,142.2,140.3,137.5,132.6,129.4,127.7$, $126.0,124.6,123.6,122.8,121.6,120.2,119.2,116.5$, 115.4, 114.2, 23.7; APCI-MS m/z found for $\mathrm{C}_{22} \mathrm{H}_{16} \mathrm{FN}_{5} \mathrm{O}_{2}$ : $401.39\left(\mathrm{M}^{+}\right)$; Anal. calcd for $\mathrm{C}_{22} \mathrm{H}_{16} \mathrm{FN}_{5} \mathrm{O}_{2}$ : C 65.83, H 4.02 F 4.73, N 17.45, O 7.97 found C $65.85, \mathrm{H} 4.06 \mathrm{~N}$ 17.43, O 7.98 .

(Z)-N-(1-(4-((Z)-(1H-Indol-3-yl)diazenyl)phenyl)ethylidene)pyrimidin-2-amine (DS-17): Maroon; Yield: 68\%; mp: $275-280{ }^{\circ} \mathrm{C} ; \mathrm{R}_{\mathrm{f}}=0.57$ (ethyl acetate/methanol 8:2); $\mathrm{R}_{\mathrm{f}}=0.54$ (ethyl acetate/methanol 8:2); IR ( $\mathrm{KBr}$, $\left.\mathrm{cm}^{-1}\right) v_{\max }: 3386,1624,1575,1465,1384,1353,1268$, 1221, 1160, 801, 746, 653, 523, 421; ${ }^{1} \mathrm{H}$ NMR $(400 \mathrm{MHz}$, DMSO- $\left.\mathrm{d}_{6}\right) \delta: 11.53(\mathrm{~s}, 1 \mathrm{H},-\mathrm{NH}-$ of indole), $8.54(\mathrm{~s}$, $1 \mathrm{H},-\mathrm{CH}(2)$ of indole), 8.19 (d, $J=4.8 \mathrm{~Hz}, 2 \mathrm{H}, \operatorname{ArH})$, 6.82-7.95 (m, 7H, ArH), 6.51-6.53 (m, 2H, ArH), 1.89 $\left(\mathrm{s}, 3 \mathrm{H}, \mathrm{CH}_{3}\right) ;{ }^{13} \mathrm{C}$ NMR $\left(100 \mathrm{MHz}, \mathrm{DMSO}-\mathrm{d}_{6}\right) \delta: 171.9$, $167.4,160.2,155.2,143.2,137.4,136.7,132.8,130.6$, $128.5,126.4,125.0,123.2,122.3,120.3,116.2,23.1$; APCIMS m/z found for $\mathrm{C}_{20} \mathrm{H}_{16} \mathrm{~N}_{6}$ : $340.38\left(\mathrm{M}^{+}\right)$; Anal. calcd for $\mathrm{C}_{20} \mathrm{H}_{16} \mathrm{~N}_{6}$ : C 70.57, H 4.74 N 24.69 found $\mathrm{C} 70.59, \mathrm{H}$ $4.78 \mathrm{~N} 24.72$.

4-((Z)-(1-(4-((Z)-(1H-Indol-3-yl)diazenyl)phenyl) ethylidene)amino)- $N$-(pyrimidin-2-yl) benzenesulfonamide (DS-19): Orange, Yield: 71\%; $R_{f}=0.67$ (ethyl acetate/methanol 8:2); IR ( $\left.\mathrm{KBr}, \mathrm{cm}^{-1}\right) v_{\max }: 3422,3358$, 3106, 3038, 2935, 2870, 2811, 2736, 1706, 1585, 1494, 1440, 1410, 1384, 1328, 1260, 1152, 1091, 941, 834, 799, 741, 683, 569, 452, 416; ${ }^{1} \mathrm{H}$ NMR $\left(400 \mathrm{MHz}\right.$, DMSO$\left.^{-d_{6}}\right)$ $\delta: 11.96(\mathrm{~s}, 1 \mathrm{H},-\mathrm{NH}-$ of indole), $9.20(\mathrm{~s}, 1 \mathrm{H},-\mathrm{CH}(2)$ of indole), $8.57(\mathrm{~s}, 1 \mathrm{H}), 8.46(\mathrm{~d}, J=4.8 \mathrm{~Hz}, 2 \mathrm{H},-\mathrm{CH}$ of pyrimidine), 8.21 (d, $J=4.8 \mathrm{~Hz}, 2 \mathrm{H}, \mathrm{ArH}$ ), 7.94-7.97 (m, 2H, ArH), 7.58-7.61 (m, 3H, ArH), 6.98-7.1 (m, $3 \mathrm{H}, \mathrm{ArH}), 6.54-6.56(\mathrm{~m}, 3 \mathrm{H}, \mathrm{ArH}), 5.98(\mathrm{~s}, 1 \mathrm{H},-\mathrm{NH})$, $1.89\left(\mathrm{~s}, 3 \mathrm{H}, \mathrm{CH}_{3}\right) ;{ }^{13} \mathrm{C}$ NMR $\left(100 \mathrm{MHz}\right.$, DMSO-d $\left.{ }_{6}\right) \delta$ : $169.7,160.7,158.3,155.0,153.2,141.3,139.6,137.2$, $135.6,131.2,128.3,127.4,126.2,124.2,122.2,121.9$, 121.1, 120.8, 116.1, 109.3, 23.1; APCI-MS m/z found for $\mathrm{C}_{26} \mathrm{H}_{21} \mathrm{~N}_{7} \mathrm{O}_{2} \mathrm{~S}$ : $495.55\left(\mathrm{M}^{+}\right)$; Anal. calcd for $\mathrm{C}_{26} \mathrm{H}_{21} \mathrm{~N}_{7} \mathrm{O}_{2} \mathrm{~S}$ : C 63.02, H 4.27, N 19.79, O 6.44 S 6.47 found C 63.05, H 4.29, N 19.76, O 6.48 .

(Z)-N1-(1-(4-((Z)-(1H-Indol-3-yl)diazenyl)phenyl) ethylidene)-N2-(naphthalen-1-yl)ethane-1,2-diamine (DS-20): Maroon; Yield: $72 \%$; $\mathrm{mp}: 110-115{ }^{\circ} \mathrm{C} ; \mathrm{R}_{\mathrm{f}}=0.42$ (ethyl acetate/methanol 8:2); IR $\left(\mathrm{KBr}, \mathrm{cm}^{-1}\right) v_{\max }$ : 3387, $1675,1582,1528,1481,1407,1277,1118,1018,959,753$, 571, 438, 418; ${ }^{1} \mathrm{H}$ NMR (400 MHz, DMSO-d $\left.{ }_{6}\right) \delta: 11.51$ (s, $1 \mathrm{H},-\mathrm{NH}-$ of indole), $8.71-8.88(\mathrm{~m}, 1 \mathrm{H},-\mathrm{CH}(2)$ of indole), 8.24-8.37 (m, 2H, ArH), 8.04-8.10 (m, 1H, $-\mathrm{CH}$ of indole), $7.15-7.50(\mathrm{~m}, 9 \mathrm{H}, \mathrm{ArH}), 6.66(\mathrm{~d}, J=8.0 \mathrm{~Hz}$, $1 \mathrm{H}, \mathrm{ArH}), 6.53-6.58(\mathrm{~m}, 1 \mathrm{H},-\mathrm{NH}-)$, 6.23-6.37 (m, 2H, ArH), 3.53-3.56 (m, 2H, CH 2$), 3.44-3.47\left(\mathrm{~m}, 2 \mathrm{H}, \mathrm{CH}_{2}\right)$, $1.89\left(\mathrm{~s}, 3 \mathrm{H}, \mathrm{CH}_{3}\right) ;{ }^{13} \mathrm{C}$ NMR $\left(100 \mathrm{MHz}\right.$, DMSO-d $\left.{ }_{6}\right) \delta$ : $170.4,159.8,146.3,140.0,139.3,135.7,134.1,132.0$, $126.9,125.6,124.5,123.5,122.3,122.0,121.3,121.1,120.2$, 118.2, 116.2, 114.3, 58.2, 47.5, 25.3; APCI-MS m/z found for $\mathrm{C}_{28} \mathrm{H}_{25} \mathrm{~N}_{5}$ : $431.21\left(\mathrm{M}^{+}\right)$; Anal. calcd for $\mathrm{C}_{28} \mathrm{H}_{25} \mathrm{~N}_{5}$ : C 77.93, H 5.84 N 16.23, found C 77.95, H 5.81 N 16.27.

(Z)-N-(1-(4-((Z)-(5-Nitro-1H-indol-3-yl)diazenyl)phenyl)ethylidene)benzo[ $d]$ thiazol-2-amine (DS-21): Dark Orange; Yield: 69\%; mp: $130-135{ }^{\circ} \mathrm{C} ; \mathrm{R}_{\mathrm{f}}=0.46$ (ethyl acetate/methanol 8:2); IR (KBr, $\left.\mathrm{cm}^{-1}\right) v_{\max }: 3567,3340$, 3119, 2922, 1668, 1618, 1523, 1455, 1388, 1355, 1162, 1121, 1061, 1017, 961, 899, 837, 785, 744, 655, 590, 480; ${ }^{1} \mathrm{H}$ NMR (400 MHz, DMSO-d $\left.\mathrm{d}_{6}\right) \delta: 11.93(\mathrm{~s}, 1 \mathrm{H},-\mathrm{NH}-$ of indole), $9.19(\mathrm{~s}, 1 \mathrm{H}, \mathrm{CH}=\mathrm{C}-\mathrm{N}-), 8.73(\mathrm{~d}, J=9.2 \mathrm{~Hz}$, $1 \mathrm{H},-\mathrm{CH}(6)$ indole), $8.56(\mathrm{~s}, 1 \mathrm{H},-\mathrm{CH}(4)$ indole), 8.41 (dd, $J_{1}=9.2 \mathrm{~Hz}, J_{2}=2.4 \mathrm{~Hz}, 1 \mathrm{H},-\mathrm{CH}(7)$ indole), 8.16$8.20(\mathrm{~m}, 2 \mathrm{H}, \mathrm{ArH}), 7.41-7.97(\mathrm{~m}, 2 \mathrm{H}, \mathrm{ArH}), 7.31(\mathrm{~d}$, $J=8.0 \mathrm{~Hz}, 1 \mathrm{H},-\mathrm{CH}(4)$ benzothiazole), $7.19(\mathrm{t}, J=7.2 \mathrm{~Hz}$, $1 \mathrm{H},-\mathrm{CH}(5)-$ benzothiazole), $7.10(\mathrm{~d}, J=7.6 \mathrm{~Hz}, 1 \mathrm{H},-$ $\mathrm{CH}(7)$ - benzothiazole), $6.96(\mathrm{t}, J=7.6 \mathrm{~Hz}, 1 \mathrm{H},-\mathrm{CH}(6)-$ benzothiazole), $1.89\left(\mathrm{~s}, 3 \mathrm{H}, \mathrm{CH}_{3}\right) ;{ }^{13} \mathrm{C}$ NMR $(100 \mathrm{MHz}$, DMSO- $\mathrm{d}_{6}$ ) $\delta: 176.9,155.9,153.2,148.5,142.5,140.6$, 138.2, 136.8, 133.6, 130.9, 128.3, 126.9, 126.0, 123.8, 122.7, 121.9, 118.8, 118.7, 111.6, 23.2; APCI-MS $\mathrm{m} / \mathrm{z}$ found for $\mathrm{C}_{23} \mathrm{H}_{16} \mathrm{~N}_{6} \mathrm{O}_{2} \mathrm{~S}$ : $440.47\left(\mathrm{M}^{+}\right)$; Anal. calcd for $\mathrm{C}_{23} \mathrm{H}_{16} \mathrm{~N}_{6} \mathrm{O}_{2} \mathrm{~S}$ : C 62.72, H 3.66, N 19.08, O 7.26 S 7.28 found C 62.75, H 3.69 N 19.04, O 7.26.

\section{Antimicrobial evaluation}

\section{Determination of minimum inhibitory concentration (MIC)}

The synthesized indole diazenyl Schiff bases were screened for antimicrobial activity through tube dilution method as per the reported procedure [41, 42]. The 
cefotaxime (antibacterial) and fluconazole (antifungal) were selected, as the standard drugs. The standard drugs and the test derivatives were dissolved in DMSO to make the stock solutions of the required concentration of $1000 \mu \mathrm{g} / \mathrm{ml}$ and further serially diluted in nutrient broth (for bacterial strains) and sabouraud dextrose broth (for fungal strains) to get the desired concentrations of (500, $250,125,62.5,31.25,15.62,7.81,3.90,1.95 \mu \mathrm{g} / \mathrm{ml})$. The each concentration of the test and standard compounds have been supplemented with $100 \mu \mathrm{l}$ of microbial inoculum to give final inoculum size of $5 * 10^{5}$ colony forming units (CFU) $\mathrm{ml}^{-1}$ under sterile conditions. The all test tubes with different concentration of the test and standard compounds and microbial strains were incubated for the specified time (for bacterial cultures $-24 \mathrm{~h}$ at $37 \pm 2{ }^{\circ} \mathrm{C}$; fungal cultures -7 days at $\left.25 \pm 2{ }^{\circ} \mathrm{C}\right)$.

\section{Determination of minimum bactericidal/fungicidal concentration (MBC/MFC)}

After MIC assessment, the indole derivatives (DS1DS21), were additionally evaluated for MBC and MFC values. To the sterilized petri plates, added $100 \mu \mathrm{l}$ of culture from each test tube which demonstrated no visible growth in MIC test tubes aseptically. The $10-15 \mathrm{ml}$ of nutrient agar and Sabouraud dextrose agar was added to the petri plates for bacterial and fungal samples respectively with gentle shaking of plates in order to mix the culture throughout the media. Allowed the media to solidify. The petri plates were then incubated for the predefined time and temperature as referenced already for bacterial and fungal cultures respectively. The plates were then investigated visually for the development of microbial growth. The MBC and MFC were stated as the minimum concentration of the compounds in aliquots showing no visual growth after incubation.

\section{Cytotoxicity study Cell culture}

The cell lines used in study were initially procured from the National Centre for Cell Sciences (NCCS), Pune, India, and maintained in DMEM. The cell line was cultured in $25 \mathrm{~cm}^{2}$ tissue culture flask with DMEM supplemented with $10 \%$ FBS, sodium bicarbonate, L-glutamine, and antibiotic solution containing: streptomycin $(100 \mu \mathrm{g} /$ $\mathrm{ml})$, penicillin $(100 \mathrm{U} / \mathrm{ml})$. Cultured cell line was kept at $37^{\circ} \mathrm{C}$ in a humidified $5 \% \mathrm{CO}_{2}$ incubator (VWR, USA).

\section{MTT cell proliferation assay}

The compounds found to have good antimicrobial potential were then screened for their cytotoxicity using MTT (3,4,5-dimethylthiazol-2-yl)-2-5-diphenyltetrazolium bromide) assay [43, 44]. $1 \times 10^{4}$ cells/well were seeded in $100 \mu \mathrm{l}$ DMEM/MEM, supplemented with $10 \% \mathrm{FBS}$ in each well of 96-well microculture plates and incubated for $24 \mathrm{~h}$ at $37{ }^{\circ} \mathrm{C}$ in a $\mathrm{CO}_{2}$ incubator. After incubation, all the prepared/synthesized compounds were added to the cells at 10, 25, 50 and $100 \mu \mathrm{g}$ concentrations for $48 \mathrm{~h}$. After $48 \mathrm{~h}$ of drug treatment, $10 \mu \mathrm{l}$ MTT $(5 \mathrm{mg} / \mathrm{ml})$ was added to each well and the plates were further incubated for $4 \mathrm{~h}$. Then the supernatant from each well was carefully removed, formazan crystals were dissolved in $100 \mu \mathrm{l}$ of DMSO and absorbance at $570 \mathrm{~nm}$ wavelength was recorded on an ELISA reader. The $\mathrm{IC}_{50}$ value was calculated using the linear regression equation i.e. $\mathrm{Y}=\mathrm{Mx}+\mathrm{C}$. Here, $Y=50, M$ and $C$ values were derived from the viability graph. The assay was performed in triplicate.

\section{Molecular docking}

The novel indole diazenyl Schiff bases were subjected to dock in the active site of DNA gyrase enzyme using Schrodinger Glide software. The 3D-crystal structure of the ATP binding site of E. coli GyrB in complex with pyrimido $[4,5-b]$ indole derivative (PDB ID: $4 \mathrm{KFG}$, resolution $1.6 \AA$ ) had been used for the modelling studies and was retrieved from Protein Data Bank (http://www. rcsb.org/pdb/home/home). The target derivatives were investigated for the theoretical binding mode at the ATP binding site to understand the ligand-receptor possible intermolecular interactions in detail using molecular docking modelling. The selected protein structure was prepared using the Protein Preparation Wizard executed in Schrödinger Suite 2018-1. Crystallographic water molecules with fewer than three hydrogen bonds were deleted. Hydrogen atoms were added to the protein structure corresponding to a $\mathrm{pH}$ value of 7 . The restrained minimization was performed until the heavy atoms RMSD reached a maximum cut-off to $0.30 \AA$. The active site was defined with a $20 \AA$ radius around the ligand present in the crystal structure and a grid box was generated at the centroid of the active site. Low-energy conformations of all ligands were docked into the catalytic pocket of the $4 \mathrm{KFG}$ protein in extra precision mode (Glide, Schrödinger 2018-1) without applying any constraints. The best docked structures were selected based on the Glide score function, Glide energy and Glide energy model $[45,46]$.

\section{ADME properties}

ADME properties were calculated using Qikprop v3.5 tool of Schrödinger. It predicts both physicochemically significant descriptors and pharmacokinetic relevant properties. QikProp provides ranges for comparing a particular molecule's properties with those of $95 \%$ of known drugs. Qikprop evaluates the acceptability of analogs based on Lipinski's rule of five, which is essential 
to ensure drug-like pharmacokinetic profile while using rational drug design. All the analogs were neutralized before being used by Qikprop.

\section{Conclusion}

In quest of effective antimicrobial and cytotoxic agents, a series of indole hybridized diazenyl derivatives (DS1-DS-21) was efficiently prepared and characterized. The synthesized derivatives were evaluated for antimicrobial activities against various pathogenic bacterial and fungal strains. Most of the synthesized derivatives especially DS-6, DS-10, DS-14, DS-20 and DS-21 demonstrated excellent antibacterial activity against Gramnegative bacteria particularly E. coli and K. pneumonia. The derivatives DS-14 and DS-20 have shown good cytotoxicity against breast cancer cell line and moderate activity against human colorectal carcinoma cell line. Most of the tested derivatives were found to be non-toxic to the leukemic cancer cell line. The synthesized derivatives revealed high safety level by exhibiting very low cytotoxicity against the normal cell line. The molecular docking studies validated the outcome results from the antimicrobial activity and signifies the potential of these derivatives as DNA gyrase enzyme inhibitors. So, these compounds can be modified further for the development of new anticancer and antimicrobial agents.

\section{Abbreviations}

DMEM: Dulbecco's Modified Eagle Medium; MEM: minimum essential medium; FBS: fetal bovine serum; MTT: 3-(4,5-dimethylthiazol-2-yl)-2,5-diphenyltetrazolium bromide; MIC: minimum inhibitory concentration; MBC: minimum bactericidal concentration; MFC: minimum fungicidal concentration; ADME: absorption, distribution, metabolism, excretion; ELISA: enzyme-linked immunosorbent assay; HEK-293: human embryonic kidney cells.
\end{abstract}

\section{Acknowledgements}

The authors are thankful to the Head, Department of Pharmaceutical Sciences, Maharshi Dayanand University, Rohtak, for providing necessary facilities to carry out this research work.

\section{Authors' contributions}

Authors BN and HK have designed and performed the synthesis, antimicrobial activity and the docking studies. The author JS have done the antiproliferative interpretations. All authors read and approved the manuscript.

\section{Funding}

The authors indebtedly acknowledge the University Grant Commission for providing SRF award to the author, H. Kaur vide Award Letter No. F.25-1/2013-14(BSR)/7-344/2011(BSR).

\section{Availability of data and materials}

Provided in manuscript.

\section{Competing interests}

The authors declare that they have no competing interests.

\section{Author details}

${ }^{1}$ Faculty of Pharmaceutical Sciences, Maharshi Dayanand University, Rohtak 124001, India. ${ }^{2}$ College of Pharmacy, Postgraduate Institute of Medical Sciences, Rohtak 124001, India.
Received: 7 January 2019 Accepted: 2 May 2019

Published online: 10 May 2019

\section{References}

1. Frieri M, Kumar K, Boutin A (2017) Antibiotic resistance. J Infect Public Health 10(4):369-378

2. Prestinaci F, Pezzotti P, Pantosti A (2015) Antimicrobial resistance: a global multifaceted phenomenon. Pathog Glob Health 109(7):309-318

3. Watkins DA, Yamey G, Schäferhoff M, Adeyi O, Alleyne G, Alwan A, Berkley S, Feachem R, Frenk J, Ghosh G, Goldie SJ (2018) Alma-Ata at 40 years: reflections from the Lancet Commission on Investing in Health. Lancet 392(10156):1434-1460

4. de Kraker MEA, Stewardson AJ, Harbarth S (2017) Will 10 million people die a year due to antimicrobial resistance by 2050? PLoS Med 13(11):e1002184. https://doi.org/10.1371/journal.pmed.100218

5. Aminov RI (2010) A brief history of the antibiotic era: lessons learned and challenges for the future. Front Microbiol 1:134. https://doi.org/10.3389/ fmicb.2010.00134

6. Ventola CL (2015) The antibiotic resistance crisis: part 1: causes and threats. Pharm Ther 40(4):277-283

7. Harrison JW, Svec TA (1998) The beginning of the end of the antibiotic era? Part I. The problem: abuse of the "miracle drugs". Quintessence Int 29(3):151-162

8. Fair RJ, Tor Y (2014) Antibiotics and bacterial resistance in the 21st century. Perspect Medi Chem 6:25-64. https://doi.org/10.4137/PMC. S14459

9. Spellberg B (2014) The future of antibiotics. Crit Care 18(3):228. https:// doi.org/10.1186/cc13948

10. The PEW, Charitable Trusts (2016) Antibiotics currently in clinical development. http://www.pewtrusts.org/ /media/assets/2016/05/antib iotics-currently-in-clinical-development.pdf. Accessed 20 Jan 2017

11. Benharroch D, Osyntsov L (2012) Infectious diseases are analogous with cancer. Hypothesis and implications. J Cancer 3:117-121. https://doi. org/10.7150/jca.3977

12. Meidani M, Naeini AE, Rostami M, Sherkat R, Tayeri K (2014) Immunocompromised patients: review of the most common infections happened in 446 hospitalized patients. J Res Med Sci 19(Suppl 1):S71-S73

13. Rolston KV (2017) Infections in cancer patients with solid tumors: a review. Infect Dis Ther 6(1):69-83

14. Alfarouk KO, Stock CM, Taylor S et al (2015) Resistance to cancer chemotherapy: failure in drug response from ADME to P-gp. Cancer Cell Int 15:71. https://doi.org/10.1186/s12935-015-0221-1

15. Tse-Dinh YC (2015) Targeting bacterial topoisomerase I to meet the challenge of finding new antibiotics. Future Med Chem 7(4):459-471

16. Kathiravan MK, Khilare MM, Nikoomanesh K, Chothe AS, Kishor S (2013) Topoisomerase as target for antibacterial and anticancer drug discovery. J Enzyme Inhib Med Chem 28(3):419-435

17. Pommier Y (2013) Drugging topoisomerases: lessons and challenges. ACS Chem Biol 8(1):82-95

18. Ehmann DE, Lahiri SD (2014) Novel compounds targeting bacterial DNA topoisomerase/DNA gyrase. Curr Opin Pharmacol 18:76-83

19. Maxwell A, Lawson DM (2003) The ATP-binding site of type II topoisomerases as a target for antibacterial drugs. Curr Top Med Chem 3:283-303

20. Sravanthi TV, Manju SL (2016) Indoles_a promising scaffold for drug development. Eur J Pharm Sci 91:1-10

21. Prakash B, Amuthavalli A, Edison D, Sivaramkumar MK, Velmurugan $R$ (2018) Novel indole derivatives as potential anticancer agents: design, synthesis and biological screening. Med Chem Res 27(1):321-331

22. Singh TP, Singh OM (2018) Recent progress in biological activities of indole and indole alkaloids. Mini Rev Med Chem 18(1):9-25. https://doi. org/10.2174/1389557517666170807123201

23. Goyal D, Kaur A, Goyal B (2018) Benzofuran and indole: promising scaffolds for drug development in Alzheimer's disease. Chem Med Chem 13:1275-1299

24. Sidhu JS, Singla R, Jaitak V (2015) Indole derivatives as anticancer agents for breast cancer therapy: a review. Anticancer Agents Med Chem 16(2):160-173 
25. Kaur H, Yadav S, Narasimhan B (2016) Diazenyl derivatives and their complexes as anticancer agents. Anticancer Agents Med Chem 16(10):1240-1265

26. Kaur H, Lim SM, Ramasamy K, Vasudevan M, Alishah SA, Narasimhan B (2017) Diazenyl Schiff bases: synthesis, spectral analysis, antimicrobial studies and cytotoxic activity on human colorectal carcinoma cell line (HCT-116). Arab J Chem. https://doi.org/10.1016/j.arabjc.2017.05.004

27. Kaur H, Narasimhan B (2018) Antimicrobial activity of diazenyl derivatives: an update. Curr Top Med Chem 18(1):3-21. https://doi. org/10.2174/1568026618666180206093107

28. Dembitsky VM, Gloriozova TA, Poroikov VV (2017) Pharmacological and predicted activities of natural azo compounds. Nat Prod Bioprospect 7(1):151-169

29. Puterova Z, Krutošíková A, Végh D (2010) Gewald reaction: synthesis, properties and applications of substituted 2-aminothiophenes. ARKIVOC 1:209-246. https://doi.org/10.3998/ark.5550190.0011.105

30. Jadhav SA, Pardeshi RK, Shioorkar MG, Chavan OS, Vaidya SR (2015) Comparative study of one pot synthetic methods of 2-amino-1,3,4thiadiazole. Der Pharma Chemica 7(2):127-131

31. Noolvi MN, Patel HM, Kamboj S, Cameotra SS (2016) Synthesis and antimicrobial evaluation of novel 1,3,4-thiadiazole derivatives of 2-(4-formyl-2-methoxyphenoxy) acetic acid. Arab J Chem 9:S1283-S1289

32. Collin F, Karkare S, Maxwell A (2011) Exploiting bacterial DNA gyrase as a drug target: current state and perspectives. Appl Microbiol Biotechnol 92(3):479-497

33. Reece RJ, Maxwell A (1991) DNA gyrase: structure and function. Crit Rev Biochem Mol Biol 26(3-4):335-375

34. Khana T, Sankheb K, Suvarnaa V, Sherjea A, Patela K, Dravyakara B (2018) DNA gyrase inhibitors: progress and synthesis of potent compounds as antibacterial agents. Biomed Pharmacother 103:923-938

35. Vickers AA, Chopra I, O'Neill AJ (2007) Intrinsic novobiocin resistance in Staphylococcus saprophyticus. Antimicrob Agents Chemother 51(12):4484-4485

36. Issa NT, Wathieu H, Ojo A, Byers SW, Dakshanamurthy S (2017) Drug metabolism in preclinical drug development: a survey of the discovery process, toxicology, and computational tools. Curr Drug Metab 18(6):556-565

37. Ntie-Kang F (2013) An in silico evaluation of the ADMET profile of the StreptomeDB database. Springerplus 2:353. https://doi. org/10.1186/2193-1801-2-353

38. Seferoglu Z, Ertan N (2007) Synthesis and spectral properties of new hetarylazo indole dyes. Russ J Org Chem 43(7):1035-1041

39. Öztürk A, Abdullah MI (2006) Toxicological effect of indole and its azo dye derivatives on some microorganisms under aerobic conditions. Sci Total Environ 358(1-3):137-142

40. Kandile NG, Mohamed MI, Ismaeel HM (2017) Synthesis of new Schiff bases bearing 1,2,4-triazole, thiazolidine and chloroazetidine moieties and their pharmacological evaluation. J Enzyme Inhib Med Chem 32(1):119-129

41. Balouiri M, Sadiki M, Ibnsouda SK (2016) Methods for in vitro evaluating antimicrobial activity: a review. J Pharm Anal 6(2):71-79

42. Cappucino JG, Sherman N (1999) Microbiology: a laboratory manual. Addison Wesley Longman Inc., California, p 263

43. Morgan DML (1998) Tetrazolium (MTT) assay for cellular viability and activity. Methods Mol Biol 79:179-183

44. Mosmanni T (1983) Rapid colorimetric assay for cellular growth and survival: application to proliferation and cytotoxicity assays. J Immunol Methods 65:55-63

45. Azam MA, Thathan J (2017) Pharmacophore generation, atom-based 3D-QSAR and molecular dynamics simulation analyses of pyridine-3carboxamide-6-yl-urea analogues as potential gyrase B inhibitors. SAR QSAR Environ Res 45:56. https://doi.org/10.1080/1062936x.2017.1310131

46. Atay ÇK, Tilki T, Dede B (2018) Design and synthesis of novel ribofuranose nucleoside analogues as antiproliferative agents: a molecular docking and DFT study. J Mol Liq 269:315-326

\section{Publisher's Note}

Springer Nature remains neutral with regard to jurisdictional claims in published maps and institutional affiliations.
Ready to submit your research? Choose BMC and benefit from:

- fast, convenient online submission

- thorough peer review by experienced researchers in your field

- rapid publication on acceptance

- support for research data, including large and complex data types

- gold Open Access which fosters wider collaboration and increased citations

- maximum visibility for your research: over 100M website views per year

At $\mathrm{BMC}$, research is always in progress.

Learn more biomedcentral.com/submissions 